\title{
Las Farc y las organizaciones comunitarias en San Andrés de Tumaco: desafíos territoriales ante una eventual implementación de los Acuerdos
}

\author{
de La Habana" ${ }^{* 1}$
}

Por Andrés Aponte** y Javier Benavides***

\section{Introducción}

$\mathrm{E}$ n la última década la costa Pacífica nariñense, y con gran acento Tumaco, ha tomado protagonismo en los medios nacionales a cuenta de los procesos violentos que ha experimentado: voladuras de oleoductos, grandes extensiones de cultivos de uso ilícito y su tráfico ilegal, amenazas y asesinatos a líderes sociales, combates entre los distintos actores armados (Farc-EP, ELN, Fuerza Pública, paramilitares y los ahora denominados Grupos Armados Posdesmovilización -GAPD-); entre otros sucesos que, además de convertirse en las imágenes más recientes de la región, ilustran un fenómeno particular: la inserción tardía y cruenta del conflicto armado en un lugar que "había estado tan olvidado por el resto del país que ni la violencia le había llegado”, según cuenta un poblador entrevistado por Agudelo (2005, p.11).

Artículo recibido en febrero de 2016.

Artículo aprobado en abrill de 2016.

** Politólogo e historiador, master en sociología. Actualmente es investigador del Cinep/PPP.

*** Politólogo e historiador de la Pontificia Universidad Javeriana, maestrante en Ciencia Política en la Universidad de los Andes.

1 Agradecemos la minuciosa lectura y comentarios de Daniela Monroy, pasante del equipo Conflicto y Estado del CINEP. 
Más allá de los estereotipos, la "huella" que ha dejado el conflicto armado en la región ha sido contundente, pues hoy en día se asocia a un lugar sin ley ni orden e inundado por la coca y las balas. Así las cosas, un acercamiento al caso de Tumaco puede resultar fundamental para comprender la relación entre pobladores locales y grupos armados en zonas donde los segundos no hacen parte de los procesos endógenos, lo cual les ha generado dificultades para vincular sus discursos y sus prácticas al no compaginarse con las de los habitantes locales.

Se hace fundamental entonces tener en cuenta -como premisa orientadora- que el conflicto armado en Colombia se ha desarrollado de manera diferenciada a lo largo del espacio y el tiempo (González, Bolívar y Vásquez, 2003), ya que la inserción de los grupos armados, sus formas de control territorial, de extracción de recursos, etc., se encuentran ligadas a los procesos previos de configuración regional. Lo anterior implica que en una eventual implementación de los Acuerdos con las Farc-EP y de la llamada Paz territorial se hace imprescindible tener en cuenta estas heterogeneidades (González, Guzmán y Barrera, 2015).

Como se mencionó anteriormente, la inserción de las lógicas del conflicto armado en la región Pacífica nariñense no se encuentra asociada a las tensiones del mundo andino (Aponte y Benavides, 2016; Vásquez, Vargas y Restrepo, 2011). Tumaco y el resto de esta zona se integran en la década del noventa a la geografía armada del país por cuenta de las decisiones estratégicas de los actores: la coca se convirtió en el principal motor para su persistencia y para el escalamiento de la confrontación. En este orden de ideas, el presente artículo se propone ponderar los retos, condicionantes y posibilidades que enfrenta el proceso de implementación de los Acuerdos de la Habana en un escenario de inserción reciente del conflicto, caracterizado por su marcado acento militarista y atravesado por la economía de la coca.

En consonancia con lo anterior, a lo largo del texto se pretenden resaltar dos aspectos nodales para comprender un posible escenario de 
posconflicto en su dimensión territorial. Por un lado, - retomando la premisa guía - la necesidad de introducir la noción de transiciones diferenciadas (Barrera, 2016; González, Castañeda y Barrera, 2016), que se asocia no solo a las capacidades dispares de un actor armado para regular e intervenir en un contexto dado, sino también a la imperiosa necesidad de construir un diseño institucional para la paz que contemple las formas variadas y cambiantes que tiene un grupo armado para interceder en la vida cotidiana, política y económica de un territorio determinado, pues estas varían de acuerdo al momento histórico y también dependiendo de si es un área de reciente expansión, de retaguardia histórica o de disputa.

Por otro lado, nos distanciamos de aquellas perspectivas que ven a los pobladores locales y las formas organizativas de la denominada sociedad civil como simples actores pasivos del conflicto que únicamente se someten al influjo y vaivén de las armas. Por el contrario, con la experiencia de San Andrés de Tumaco queda en evidencia que la gente no solo resiste, también se adapta, negocia y aprende. Es decir que la que la historia pesa, y mucho.

Los tumaqueños, y en general los pobladores del Pacífico nariñense, se caracterizan por ser una sociedad multiétnica, con territorialidades producidas por poblamientos diversos, lo cual le ha impedido a las Farc-EP influir de forma amplia en la vida comunitaria a la vez que ha dado a las pobladores locales herramientas y elementos para defender y fortalecer sus procesos organizativas endógenos. Al lado de los efectos negativos que ha tenido el conflicto armado sobre los procesos organizativos, resaltados por otros estudios -anomia, desarticulación, ruptura, asesinatos y exilio de líderes, preferencias por medidas autoritarias, etc., (Arjona, Cárdenas, Ibáñez, Justino y Martínez, 2016) -, hay también "legados positivos" en medio de este preocupante saldo de violencia letal que poco han sido resaltados y que pueden ser claves para la coyuntura venidera. 
Es importante señalar que en este artículo el lente se posa casi exclusivamente sobre las Farc-EP, pues este grupo nos interesa por varios factores. En primer lugar, están aquellos de orden nacional y coyunturales, que ya esbozamos más atrás; en segundo lugar, en el plano regional y local cuentan los motivos de su inserción en la zona, asociados a aspectos militares (Seguridad Democrática y el Plan Colombia) y económicos (introducción de los diversos eslabones de la economía de la coca) que a su vez están relacionados con la escala maestra de la guerra (Kalyvas, 2006); finalmente, nos interesa por el gran protagonismo militar y la posición "hegemónica" que han tomado en el municipio de Tumaco y en la región en general.

Para desarrollar los puntos esbozados, y como camino para motivar la discusión a propósito de los desafíos territoriales de la paz en zonas fuertemente golpeadas por el conflicto armado, el siguiente artículo se organiza en cuatro grandes apartados: el primero, interesado en las dinámicas de poblamiento y configuración regional que nos explicarán las formas de organización social presentes, las actividades económicas dominantes, así como los mecanismos de intermediación política, de regulación y de inserción a la vida nacional, etc. Estos factores tienen relevancia respecto a las formas y modalidades en que los actores armados se insertan y asientan en un territorio determinado, pues estos, al igual que los estados (Mann, 1992, 2006; González, 2014), no se asientan sobre espacios vacíos. De ahí que comprender los procesos sociohistóricos de la región permite explicar los mecanismos de regulación social y las fronteras porosas entre Estado y sociedad en la vida local.

En segunda instancia, se propone un panorama general de las principales lógicas y dinámicas del conflicto armado en la región, enfatizando en el caso de las Farc-EP, en el que remarcamos no solamente su momento de inserción, sino también las apuestas y resultados de su expansión al municipio de San Andrés de Tumaco. En tercer lugar, se hace una aproximación general de aquellas formas organizativas sociales y comunitarias, sus momentos de auge y su interacción con los 
procesos violentos, para con ello brindar -a manera de conclusión- una serie de elementos a tener en cuenta en el proceso de proyección de los acuerdos de paz de La Habana en este territorio. En esta vía, haremos una serie de recomendaciones que, más que conclusiones, pretenden ser una hoja de ruta para señalar los diversos procesos o elementos que pueden resultar explosivos o habilitantes para los acuerdos de La Habana en los años venideros ${ }^{2}$.

\section{Poblamiento y configuración de Tumaco: entre ríos, palma y coca}

San Andrés de Tumaco es un municipio del departamento de Nariño ubicado en el extremo suroccidental de Colombia, en la región del Pacífico nariñense. Es el municipio de mayor extensión del departamento ${ }^{3} \mathrm{y}$ se encuentra a $300 \mathrm{~km}$ de la capital departamental, San Juan de Pasto. Está situado en una subregión atravesada por importantes y numerosas cuencas fluviales ${ }^{4}$, entre las que se encuentran algunos de los ríos que

2 Como fuentes de este artículo se emplean una revisión crítica de los diferentes estudios acerca de la historia social y política de Tumaco y el Pacífico nariñense, entrevistas e intercambios realizados en el segundo semestre de 2015 y el primero de 2016, así como acercamientos recientes con líderes comunitarios de Tumaco, Barbacoas y Francisco Pizarro.

El interés fundamental de las entrevistas e intercambios fue conocer las percepciones e impactos del conflicto en los Consejos Comunitarios. Aunque somos conscientes de la necesidad de enriquecer el abordaje de otras miradas, por ejemplo aquella de los colonos cocaleros, no fue posible el acercamiento por la coyuntura de seguridad en algunas zonas rurales. En ese sentido, esta es una primer entrada con miras a lograr conocer el fenómeno en su complejidad: poder complementar este estudio con las otras miradas de sectores organizados y comunitarios de Tumaco es un asunto a desarrollar en próximas investigaciones.

3 Representa el 12 \% del territorio del departamento de Nariño. "La población total en el Municipio de Tumaco asciende a 163.102 habitantes, distribuidos para la zona rural en 76.197 habitantes en un área de 360.172,938 Hectáreas, para una densidad de 0.23 hab/ha; y, para la zona urbana 86.905 habitantes en un área de 1.375,359 hectáreas para una densidad de 61 hab/ha" (Alcaldía, 2015, 13).

4 Vale resaltar los ríos Alcabí, Chagüí, Guiza, Mataje, Mejicano, Mira, Nulpe, Patía, Pulgandé, Rosario y San Juan. 
desembocan en el océano Pacífico, así como abundantes bosques tropicales. Limita al norte con el municipio de Francisco Pizarro, al sur con la provincia de Esmeraldas (Ecuador), al este con los municipios de Roberto Payán y Barbacoas y al oeste con el océano Pacífico. Las actividades económicas de sus pobladores, que tienen graves precariedades sociales y económicas, se basan en la agricultura ${ }^{5}$, la pesca, la actividad forestal, el turismo (Alcaldía, 2015) la palma y, más recientemente, la economía cocalera.

El municipio de Tumaco presenta, a grandes rasgos, una dinámica de poblamiento y configuración marginal atada a diferentes ciclos extractivos nacionales, como el oro, la tagua, el caucho, la madera y la palma, hasta llegar a los cultivos de coca. La presencia estatal ha sido históricamente precaria, lo que ha redundado en la emergencia de procesos sociales de organización de las comunidades autónomos -mas no autárquicosen torno al gobierno del territorio (Hoffmann, 2007) y al margen de las directrices del Estado y del bipartidismo tradicional. Esta situación contrasta con la de algunas zonas del país, como es el caso de Caquetá, Meta y Magdalena medio, entre otras, cuyos procesos de poblamiento y colonización se presentaron vinculados a las problemáticas de acceso y uso de la tierra propias del mundo andino (Vásquez, 2015; Vásquez, Vargas, Restrepo, 2011), a veces dirigidas por el Estado y el bipartidismo y otras veces "apoyados" por contingentes de gente armada (Molano, 2014; Jaramillo, Cubides y Mora, 1989; González, 1992).

Bajo esta idea central, más allá de la remota presencia de pequeñas comunidades indígenas (telembíes, barbacoas, sindaguas e iscuandés), el proceso de poblamiento en Tumaco tuvo como punto de arranque la economía minera con mano de obra esclava que se desarrolló en la Colonia (siglo XVIII), con epicentro en Barbacoas e Iscuandé (Moore, 1993), y que se extendió hasta el siglo XIX, pues con la manumisión de

Según la página web del municipio, en Tumaco se produce el $100 \%$ de la palma africana, el $92 \%$ del cacao y el 51 \% del coco del departamento de Nariño. 
los esclavos de las cuadrillas mineras se fueron poblando poco a poco las zonas más apartadas del Pacífico nariñense. No obstante, no fue sino con el auge de la tagua que Tumaco se tornó un centro poblado de importancia y empezó a jugar un papel preponderante en la región (Escobedo y Palacio, como se citaron en Rodríguez, 2015).

Su configuración como epicentro regional llevó consigo una dinámica dual de poblamiento: por un lado la población afro-liberta, distribuida a lo largo de las cuencas y subcuencas de los principales ríos (Mira, Mejicano, Rosario, entre otros), los cuales no eran solo las vías de transporte y comunicación sino que originaron dentro de los pobladores un "sentido de lugar”, de representación del espacio y el territorio (Oslender, 2007); y por otro lado la población blanca y mestiza (la élite regional), usualmente proveniente de los centros andinos, la cual se concentró en la parte urbana y estaba atada a las lógicas comerciales del mercado internacional (tagua y algunos productos maderables como el caucho) (Rodríguez, 2015; Laurent, 2008; Leal; 2005).

La importancia de esta actividad económica radica en que produjo un aumento poblacional y la consolidación de una élite comercial y política desde finales del XIX, conformada por antiguos miembros de la élite barbacoana, como las familias Manzi, Delgado o Escrucería (Rodríguez; 2015; Helfrich, 2000; Preciado, 2014), que se entrecruzaron y lograron unificar y solidificar una élite económica y política para el Pacífico nariñense bajo un sistema clientelista-paternalista que tuvo como mejor expresión a Samuel Alberto Escrucería, 'El Beto', y todo su clan familiar.

Los Escrucería, a la cabeza de 'El Beto', detentaron el monopolio de la intermediación política durante buena parte del siglo XX aprovechando la contradicción existente entre serranos (mundo andino nariñense) y costeros (mundo pacífico). También integraron a la vida política a los habitantes rurales por medio de una lógica clientelista que perdura hasta el día de hoy y que significó la delegación del poder administrativo y regulador del Estado central y regional sobre su persona. No en vano, 
[Al Beto] la clase política de la sierra lo escuchaba, no tanto por que quisiera, sino simplemente porque necesitaban sus votos o le temían. En Bogotá lo protegían porque era el representante del Partido Liberal en una región en donde el Estado no hacía presencia. Era el señor de la costa, él era el Estado en la Costa. (Oviedo, 2009, como se citó en Preciado, 2014, p.13).

Con el fin del boom de la tagua y el caucho, entre los años cuarenta y setenta se fue transitando a una nueva actividad: la extracción maderera. Su importancia radica en que produjo un impulso "modernizador", así como cambios importantes en la estructura socioeconómica y en los hábitos de consumo de la región; también dinamizó un crecimiento demográfico sustancial (Gráfica 1) y abonó al surgimiento de tensiones y expresiones sociales que se mantienen hoy en día (Restrepo, 1999). El principal antecedente para este auge maderero es la Ley 2 de 1959, que declaró baldío a un gran conglomerado de tierras del Pacífico colombiano que anteriormente estaban catalogadas como Zona de Reserva Forestal - ZRF - , lo cual desconoció y ocultó la presencia histórica de comunidades rurales afro e indígenas en la zona (Hoffman, 2007; Restrepo 1999).

Así, se dio una migración "voluntaria” y forzada de campesinos en busca de oportunidades hacia los principales centros urbanos, Barbacoas, Iscuandé y mayoritariamente Tumaco, pero también emergió una conflictividad social a cuenta de la llegada de las empresas de explotación de madera y la expulsión de las comunidades negras de sus territorios (Rodríguez, 2014) ${ }^{6}$. Este proceso abrió la puerta a un periodo de vigorosa

6 A ello hay que sumar el impacto ambiental y social de la extracción maderera, que la llevó al fracaso. El primero inició a fines de los años setenta, en zonas del norte de la región del Pacífico nariñense, a raíz del grave impacto por la construcción del Canal Naranjo, que unía los ríos Patía y Saquiangua, y produjo una fuerte reacción por parte de las diferentes comunidades rurales afectadas por esta medida. El segundo, producido por las precarias condiciones laborales y la debacle de la industria maderera, que junto a otros fenómenos como el terremoto del 79 produce una crisis social sin precedentes (Oviedo, 2009). 
organización y movilización social urbana, que junto a las anteriores reivindicaciones tendría como expresión culmen el movimiento cívico de los ochenta y el 'Tumacazo'7 en 1989 (Oviedo, 2009).

\section{Gráfica 1. Censos de San Andrés de Tumaco 1905-2005}

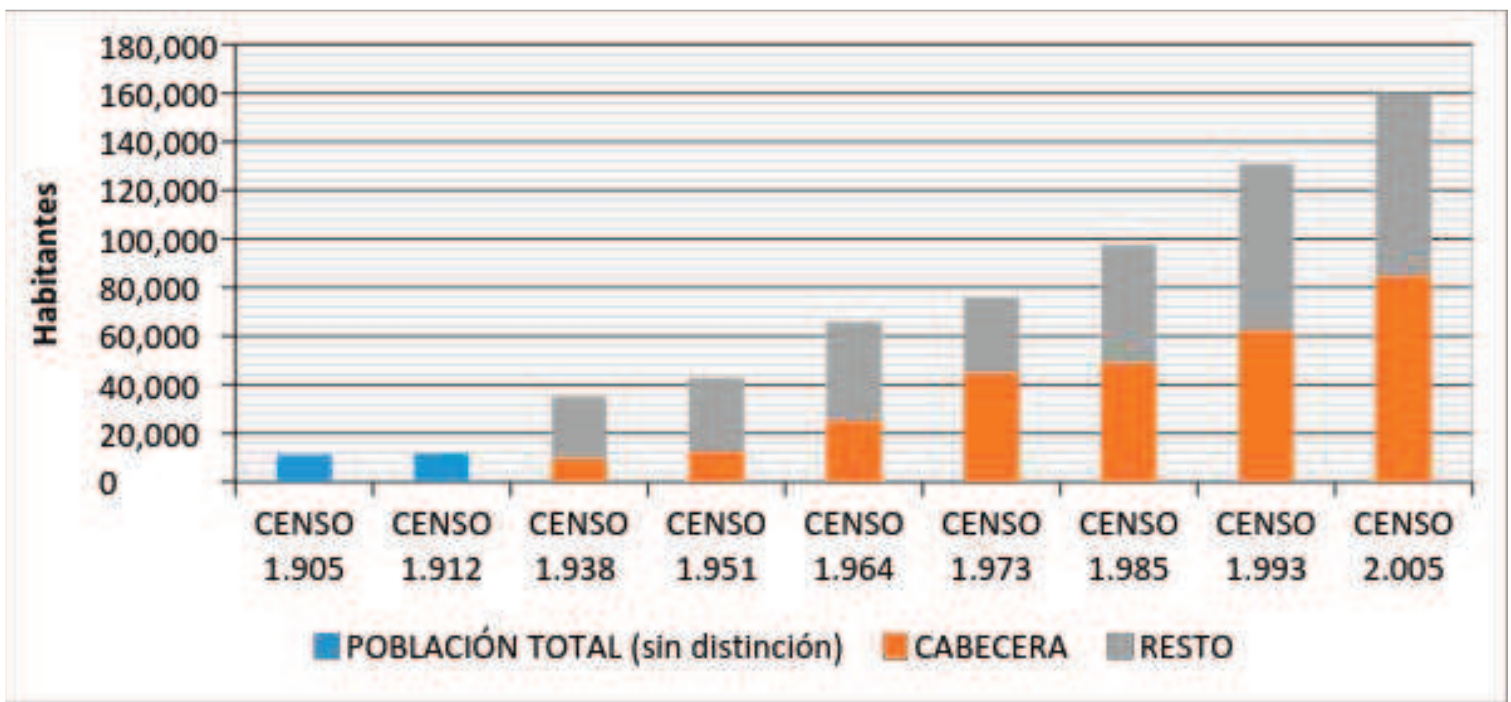

Fuente: Dane. Elaboración propia

A finales de la década de los ochenta culminó el auge de la extracción maderera e inició la introducción de la palma. Esta agroindustria agudizó los conflictos por la tierra entre los habitantes rurales y los empresarios regionales, ya que los territorios ancestrales de las comunidades negras se vieron afectados por la expansión de este monocultivo. No en vano, en la década de los noventa, favorecido por la legislación nacional, el cultivo de la palma llegó a comprender el $46 \%$ del territorio de Tumaco (García, 2011; Rodríguez, 2015; Quiroga y Yunis, 2012) bajo diversas modalidades: la compra de tierras, la presión -por medio de amenazas y desplazamiento - a los pobladores rurales y vías de hecho con el arribo paramilitar (Anexos: Gráfica 4). En el año 2004 la enfermedad del cogollo atacó el 90 \% de los cultivos de la zona, por lo cual en la

Se le denomina así a una revuelta popular en la ciudad de Tumaco por cuenta del incumplimiento del gobierno por la prestación de energía eléctrica. 
actualidad se encuentran un poco diezmados los cultivos (Rocha, como lo citó Rodríguez, 2015); pero, según cuentan los pobladores, los reclamos por la afectación de los territorios colectivos son persistentes hasta el día de hoy (Conversación con líderes de Tumaco, Francisco Pizarro y Barbacoas; entrevistado 12).

En la década del noventa continuaron y emergieron nuevos procesos y lógicas que se entrelazaron de forma contingente, que fueron integrando más a Tumaco a la vida nacional. No obstante, este movimiento se dio de forma traumática y conflictiva, situación que explica la emergencia de un contexto complejo y explosivo. En este orden de ideas, señalamos, en primer lugar, un mayor interés por parte del Estado de integrar vía institucionalización del desarrollo la macrorregión Pacífica, a cuenta de sus riquezas naturales y su importancia geoestratégica (Agudelo, 2005; Castillo, 2007). Esta postura generó una presencia caótica de la maquinaria estatal, de organizaciones de cooperación y no gubernamentales, al implementar contradictoriamente diferentes proyectos productivos, de conservación ambiental, de participación y de racionalización institucional en pleno reajuste del modelo económico (Quiroga y Yunis, 2012).

En segunda instancia, y atado a lo anterior, la Constitución de 1991 y la descentralización política y administrativa potenciaron la competencia política local, en pleno desgaste y agotamiento del clan Escrucería, mas no de las formas de hacer política. Así, las autonomías en materia administrativa y presupuestal hicieron de la Alcaldía un botín para gamonales históricos y emergentes ${ }^{8}$, con lo cual se abrió la posibilidad para que estos intentaran construir su propia red y monopolizar la intermediación política con el nivel nacional y regional, entablando acuerdos con los

8 Por gamonales históricos entendemos a aquellos asentados por décadas en la política tumaqueña, primordialmente herederos o parte de la maquinaria construida por el clan Escrucería. Por el contrario, cuando se hace referencia a los “emergentes" nos referimos a aquellos políticos, medianos jefes locales, líderes sociales y comunitarios, entre otros actores, que emergen en la competencia política con la debacle de los Escrucería. 
actores armados si lo veían necesario (Aponte y Benavides, 2015). Esto explica la intensa competencia electoral que ha experimentado el municipio en los últimos años (Preciado, 2014; Helfrich, 2000; Rosero, 2012).

Además, como tercer factor, la nueva constitución y el reconocimiento de la multiculturalidad dentro del Estado, así como la puesta en marcha de la Ley 70 de 1993, construyeron todo un modelo de territorialidad colectiva afro -los Consejos Comunitarios - inspirado en la experiencia indígena (Castillo, 2007), el cual se convirtió en una estructura de oportunidad política para la titulación colectiva de tierras y el fortalecimiento de los procesos comunitarios afro.

No obstante, esos procesos organizativos que se van configurando con la promulgación de la Ley 70, así como la vida económica y política local, empezaron a verse afectados por la inserción de las dinámicas del conflicto armado y de la economía de la coca. Esto inauguró el nuevo ciclo económico cocalero y cocainero, el cual se convirtió en el activo principal de la expansión y desarrollo del conflicto armado en la región (García, 2011). En efecto, este proceso se potenció por tres factores: las ventajas geográficas que brinda la zona, el traslado de cultivos del bajo Putumayo por las fumigaciones y la puesta en marcha del Plan Colombia (Ramírez, 2001; Torres, 2012; Vásquez, Vargas y Restrepo, 2011), y las "herencias" del narcotráfico en la zona - especialmente del Cartel de Cali-, que significaron una relación de las élites políticas con la criminalidad (Vásquez, Vargas y Restrepo, 2011). De ahí el aumento sostenido en el tiempo de la extensión de los cultivos de coca, así como la edificación de todo un clúster cocalero.

Estos factores, además de dinamizar e intensificar la disputa entre los actores armados, dieron lugar a un nuevo fenómeno de poblamiento (Gráfica 1): la colonización colono-cocalera de tipo mestizo atada a esta economía, la cual ha modificado y afectado las formas de apropiación territorial y los distintos procesos organizativos, preponderantemente afro y bajo la figura de los Consejos Comunitarios. 
Como corolario, en este periodo la región pasó de ser una zona de refugio y descanso para las guerrillas a convertirse en un territorio central en la escala nacional de la guerra, rompiendo con una relativa "vida pacífica”. Esta integración conflictiva y traumática complejizó y transformó los procesos de organización social y de apropiación territorial, pues la oferta institucional y su manera de ser aprehendida en lo local generó tensiones por cuenta de formas yuxtapuestas de territorialización y organización comunitaria (Aponte y Benavides, 2016). Así se constituyó una "geometría del poder variable" (Hoffman 2002, 2007; Rivas, 1999); es decir que en un mismo territorio se traslapan el marco institucional con formas endógenas de regulación y organización cambiantes en el tiempo y en el espacio?.

En ese orden de ideas, a continuación se sugiere una tipología que da cuenta de los mecanismos y dispositivos de organización que han tenido lugar en Tumaco ${ }^{10}$. Partiendo de lo construido por Hoffman (2002) ${ }^{11}$, señalamos los principales mecanismos y formas organizativas propias de ese proceso socio-histórico y sugerimos un nuevo tipo, asociado a la dinámica del conflicto armado y los procesos derivados de este:

- Mecanismo fluvial-ribereño: echa raíces en el poblamiento inicial, caracterizado por la fundación de poblados y veredas a lo largo de los ríos. Por su carácter, construyó formas flexibles de propiedad individual y espacios de usufructo común. La estructura de poder y autoridad se fundamenta en

9 En el trabajo de Hoffman serán catalogados como dispositivos espaciales. Para afectos de este trabajo las denominaremos como jurisdicciones o estatutos informales, dado el énfasis en entender no solamente su ubicación y presentación espacial, sino su dimensión política y de regulación social y comunitaria.

10 No obstante esto no quiere decir que se han presentado rupturas entre uno y otro. Todo lo contrario, estos se han transformado y trastocado en el tiempo, y son precisamente los que permiten entender la riqueza y complejidad que hay en al área de estudio.

11 En el cúmulo de sus trabajos Hoffman habla de dispositivos socio-espaciales. En el presente texto preferimos asumir la definición de mecanismos que se encuentra acorde al trabajo. 
el prestigio y el parentesco asociado a las familias fundadoras de los poblados (Hoffman, 2007), lo cual dio lugar a la constitución de múltiples "jefes políticos micro locales" (Rivas, 1999) que integraron inicialmente la localidad a las redes del Partido Liberal y sirvieron como base para la hegemonía de los Escrucería (Hoffman, 2002, 2007; Rivas, 1999). Estas autoridades tradicionales se han visto afectadas con los procesos de modernización, la oferta institucional reciente y los grupos armados.

- Mecanismos y actores "modernizantes": fruto de los primeros asomos de ordenamiento y de modernización desde el centro, emergieron nuevas figuras y formas de participación y administración local (corregimientos y sus respectivos corregidores, las JAC, entre otras), que en un principio fueron mecanismos para que las comunidades de los ríos usaran como puente de comunicación con "el exterior", pero que terminaron trastocando ciertos ámbitos de la vida comunitaria por la emergencia de nuevos liderazgos ${ }^{12}$.

- Mecanismos de organización social institucionalizada: se trata de formas organizativas apropiadas a través de una oferta institucional caótica del Estado (década 90), en donde se asimilaron y reinventaron formas de organización de los pobladores bajo el discurso afro, siendo los Consejos Comunitarios su mayor expresión. Más allá de sus limitantes, dificultades e incapacidades, han sido una nueva forma de gestionar, dividir y representar el espacio (Hoffman, 2007) ${ }^{13}$. Dentro de estos mecanismos se encuentran también otras formas organizativas (cooperativas, asociaciones, fondos, etc.) relacionadas con proyectos productivos, sociales o culturales

12 Son ejemplo de ello las obras de caminos, anteriormente desarrolladas en mingas (Hoffman, 2007), que pasaron a estar bajo la tutela de las JAC y la negociación con el municipio, que ya no se hacía a partir de la representación o figura de las autoridades de los viejos, en los ríos, sino que fue reglamentada y desarrollada por los corregidores.

13 Esta nueva oferta institucional asimilada y reglamentada por el Estado reconoce los derechos colectivos a diferentes territorios de los ríos, con autoridades reglamentadas por la ley: juntas de gobierno y asambleas de pobladores. 
en el territorio, los cuales tiene legitimidad local fluctuante y muchas veces dependiente de los recursos a disposición (Hoffman, 2007).

- Mecanismo colono-cocalero: formas organizativas fruto del arribo reciente de contingentes poblacionales de colonos mestizos ${ }^{14}$ ligados principalmente a la economía de la coca. Son el resultado de la presencia y regulación de facto de las Farc-EP y reflejan la entrada en contradicción de dos órdenes sociales: uno étnico-territorial (a la cabeza de los Consejos Comunitarios) y otro colono-cocalero, representado en asociaciones o juntas de colonos que no solo coinciden con las jurisdicciones de los Consejos Comunitarios, sino que muchas veces han cuestionado su autoridad y legitimidad a la hora de establecer los mecanismos internos de regulación social, la misma conformación de las juntas, la capacidad de movilidad de los habitantes locales, etc.

\section{Organizaciones sociales y comunitarias en el entramado local}

Además de la inserción tardía del conflicto armado en su territorio, otra de las principales características de la sociedad tumaqueña ha sido una doble condición de clientelismo exacerbado y de permeabilidad de la política sobre la vida social y cultural local. Este asunto, lejos de ser contradictorio, devela otras formas de expresión política, espontáneas u organizadas, que hacen parte de una tradición de movilización y organización social importante impulsada desde los años setenta, la cual es fundamental para entender las posibilidades y vicisitudes que enfrenta un escenario de transición y de posconflicto en la región, aunque ha encontrado serias dificultades para insertarse en el poder local.

14 En su mayoría compuesta por contingentes poblacionales de Putumayo, Caquetá y Huila, entre otros. 


\section{Gráfica 2.}

\section{Evolución de la movilización social en San Andrés de Tumaco $1975-2014$}

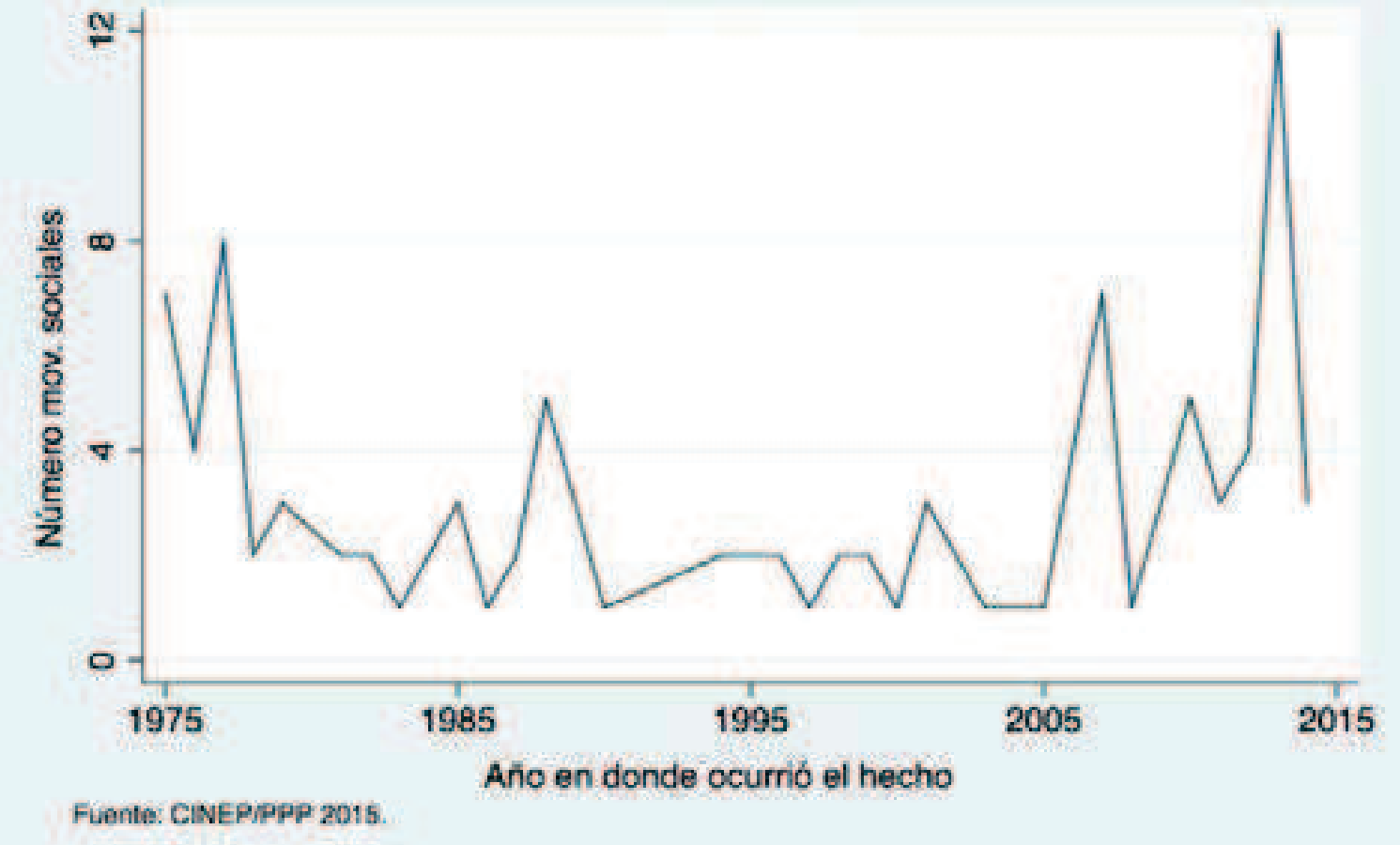

Como antecedentes e influencias es posible señalar cuatro grandes procesos claves en la historia social y política del municipio y la región. En primer lugar se dio la experiencia agraria y sindical de las década del setenta y el ochenta, que estuvo asociada a conflictos por la tierra y conflictos laborales de los diferentes ciclos extractivos que mencionamos. En segundo lugar, y atado a lo anterior, se desarrolló el movimiento cívico, que se convirtió en protagonista principal de las movilziaciones de los años ochenta y noventa al señalar el abandono estatal en medio de una crisis social sin precendentes. Este movimiento, que también fue un actor importante en el marco del desgaste del betismo, tuvo como hito fundamental el 'Tumacazo’ en 1988 (Oviedo, 2009; Hoffman, 1999).

En tercer lugar, aparecieron nuevos actores étnico-territoriales con la promulgación de la Ley 70 de 1993 y su implementación con la puesta en 
marcha del Decreto 1745 de 1995. En este proceso, a partir de la oferta institucional emergió el Palenque Nariño, capítulo del Proceso de Comunidades Negras y principal expresión organizativa que cuenta con el apoyo de actores de la cooperación, la Iglesia y algunos estamentos del Estado que lideraron el proceso de titulación colectiva. Dicho proceso ha estado atravesado por vicisitudes, pero significó a todas luces una ventana de oportunidad política para que las comunidades rurales conocieran y se apropiaran de la Ley. En este orden de ideas, se comprende que desde los años noventa, y hasta el 2005, las organizaciones sociales tumaqueñas buscaron leer, apropiarse, asimilar y coordinar organizativamente la nueva legislación estatal (Hoffman 2007; Oslender, 2007).

En cuarto lugar, es importante refereise a las movilizaciones por parte de las comunidades y personas afectadas por el conflicto armado en la última década ${ }^{15}$ (2005-2014), que evidencia un nuevo punto de inflexión en la movilización relacionado esta vez con los impactos de la guerra a cuenta de asesinatos selectivos por parte de paramilitares y de las Farc-EP, de tal forma que conjugan su rechazo a la guerra con la exigencia de derechos. Por último, vale la pena resaltar también las movilizaciones de sectores campesinos y cocaleros en el ámbito rural asociadas a los coletazos del Paro Nacional Agrario, que tuvieron como repertorio la toma de carreteras, experiencia que tiene poca relación con los repertorios de protesta que estas comunidades han emprendido habitualmente ${ }^{16}$.

15 De igual forma, también es importante resaltar en este periodo una participación intermitente de sectores campesinos, sindicales y estudiantiles. No obstante, si observamos los motivos principales así como las coyunturas que activan ciclos más activos de movilización, son los actores arriba nombrados los que en su mayoría capitalizan la movilización social.

16 Un dirigente del Alto Mira nos expresaba: "A veces nos han obligado a salir a marchar a tomar carreteras, pero nosotros no sabemos hacer eso, nunca lo hemos hecho. Es más, en qué carreteras íbamos si nuestras carreteras son los ríos" (Entrevista 12). 


\section{La heterogeneidad del mundo social y comunitario tumaqueño.}

Estos procesos de movilización y organización social, que han sido cambiantes en el tiempo, en sus formas y repertorios, implican que en la actualidad existen diferentes actores sociales y comunitarios en la vida local. Así las cosas, encontramos:organizaciones étnico territoriales (Consejos Comunitarios), resguardos indígenas, asociaciones de campesinos, Juntas de Acción Comunal, procesos organizativos relacionados con proyectos productivos, organizaciones culturales y asociaciones de jóvenes, personas afectadas por el conflicto armado, etc. Estas experiencias organizativas muchas veces se solapan entre sí y sus miembros se mueven en varias de ellas, lo cual pone de relieve la complejidad del asunto y lo caótico que puede resultar la oferta institucional y la acción de la cooperación internacional. No en vano se han generado tensiones y disputas entre las diversas formas organizativas.

Tumaco cuenta con diecisiete resguardos indígenas, aglutinados en una organización de segundo nivel: Unipa. Estos suman aproximadamente 11.199 habitantes, de los cuales el 99,3 \% se localiza en la zona más alta del municipio, en el extremo oriental y nororiental, y el $1,27 \%$ restante cerca de la carretera. Algunos de estos resguardos son compartidos con los municipios de Barbacoas, Mallama o Ricaurte (Concejo Municipal, 2013).

Asimismo, desde los años sesenta al día de hoy se encuentran registradas más de 450 Juntas de Acción Comunal, lo cual da cuenta de una importante organización que tuvo protagonismo en la movilización social del municipio. Sin embargo, tal y como denota el trabajo de Kaplan (2001), Tumaco tiene una menor densidad de juntas en comparación al Pacífico norte y a otras zonas del país con un impulso mayor de las JAC. En la actualidad las Juntas del municipio son 
organismos construidos a lo largo de los corregimientos especiales de carretera y en los diferentes barrios de las cinco comunas del casco urbano $^{17}$.

Las JAC son distintas a aquellos organismos producto de la colonización cocalera que hemos denominado juntas o asociaciones campesinas y de colonos, muchas veces soslayadas y yuxtapuestas en territorios de jurisdicción de los Consejos Comunitarios o Resguardos Indígenas. Esto se da sobre todo en las zonas de carretera: Tangareal, Espriella, Candelillas, Llorente, La Guayacana y San Juan de la Costa, son los corregimientos más representativos.

Por último, en este panorama variopinto hay que resaltar los Consejos Comunitarios, que están agrupados en Recompas, organización de segundo nivel que al día de hoy suma dieciséis Consejos, los cuales están repartidos a lo largo y ancho del municipio. Cada uno de estos Consejos, según sean su proceso de configuración y sus miembros, tiene sus particularidades y un tipo de relación propio con el centro municipal. La tabla a continuación pone de relieve que el asunto de los Consejos Comunitarios está rodeado de experiencias muy disimiles en cuanto a potencial de familias que agremian, territorio y relación con la vida urbana.

Se encuentra pendiente un ejercicio para ubicar y definir cuáles de esas 450 JAC registradas realmente existen en la actualidad. 


\section{Tabla 1. Distribución Poblacional de los territorios colectivos afrocolombianos de Tumaco}

\begin{tabular}{|c|c|c|c|}
\hline $\begin{array}{c}\text { Consejo } \\
\text { Comunitario }\end{array}$ & Área (Hectáreas) & Población & $\begin{array}{c}\text { Cantidad de } \\
\text { veredas }\end{array}$ \\
\hline Acapa $^{18}$ & 94.400 & 9.000 & 32 \\
\hline Bajo Mira Frontera & 46.681 & 8.029 & 53 \\
\hline Alto Mira Frontera & 28.000 & 7.677 & 42 \\
\hline Unión río Chagüí & 27.215 & 7.231 & 27 \\
\hline Unión río Rosario & 10.648 & 6.840 & 15 \\
\hline $\begin{array}{c}\text { Cortina Verde } \\
\text { Mandela }\end{array}$ & 1.204 & & 5 \\
\hline Rescate Las Varas & 15.000 & 5.948 & 15 \\
\hline $\begin{array}{l}\text { Veredas Unidas un } \\
\text { bien común }\end{array}$ & 13.170 & 1.309 & 3 \\
\hline Río Mejicano & 13.274 & 2.918 & 4 \\
\hline Río Tablón Salado & 3.115 & 1.028 & 5 \\
\hline $\begin{array}{c}\text { Unión vereda del } \\
\text { río Caunapí }\end{array}$ & 5.000 & 1.500 & 14 \\
\hline Río Gualajo & 2.775 & 712 & 4 \\
\hline Tablón Dulce & 1.600 & 750 & 1 \\
\hline $\begin{array}{c}\text { Imbilipi del } \\
\text { Carmen }\end{array}$ & 2.783 & 381 & 1 \\
\hline La Nupa & 183 & 351 & 1 \\
\hline
\end{tabular}

Fuente: Acuerdo No. 19. Ajustes a Plan de Desarrollo de la administración Municipal de San Andrés de Tumaco 2012-2015 (Noviembre de 2013).

18 Comparte área con el municipio de Francisco Pizarro y Mosquera. 


\section{El movimiento de comunidades negras en Tumaco: de la reinvención a la impotencia}

El movimiento de las comunidades negras en Tumaco, atado a las transformaciones y reconocimientos de la Constitución del 91 y en consonancia con experiencias similares en otras regiones del país, atravesó durante la década de los noventa todo un proceso de reconocimiento, asimilación y reinvención que le permitió potenciarse como un actor en la política nacional, con gran repercusión e incidencia en lo local (Castillo, 2007; Agudelo, 2005). No obstante, a pesar de sus logros y apuestas, en la práctica tuvo -y ha tenido- que enfrentar serios retos internos, así como aquellos asociados a los impactos de la dinámica del conflicto armado y de la violencia generalizada en algunos territorios.

Siguiendo a Agudelo (2005) y Castillo (2007), el proceso inicialmente enfrentó varios avatares, como por ejemplo la indefinición del marco que reglamentara y concretara los parámetros y mecanismos de participación de las comunidades negras. Esto retrasó el proceso, pero, aun en medio de incertidumbres, se dieron las primeras apuestas e iniciativas de socialización y organización a lo largo de ríos emblemáticos a cargo de Palenque Nariño, capítulo territorial del Proceso de Comunidades Negras $^{19}$. Esta organización contó, además, con el apoyo y la participación de intelectuales, jóvenes urbanos y dirigentes provenientes de organizaciones campesinas, de educación popular y movimiento cívico, así como con un fuerte apoyo de distintas ONG y la Iglesia (Agier y Hoffman, 1999).

19 En medio de confusiones y debates en torno a la reglamentación y la titulación colectiva afro, tal y como lo evidencian Castillo (2007) y Agudelo (2005), tras arduos debates se reproduce el modelo de los Resguardos; algo clave para entender el proceso mismo de conformación, pero también para alejarse de las posturas que idealizan los Consejos Comunitarios sin entenderlos como construcciones históricamente dadas. 
A partir de la Ley 70 del 93 y el Decreto 1745 del 95, que reglamentó el proceso de constitución y las formas organizativas de los Consejos Comunitarios, en el Pacífico nariñense hubo un boom del discurso negro y unos mayores niveles de organización y movilización social, pero este proceso se materializó a un ritmo más lento si se compara, por ejemplo, con distintas zonas del Chocó. Lo anterior se explica a causa de que solamente se aprobó la organización de Consejos en los lugares más recónditos del departamento y en zonas que no representaban riesgo de conflicto. En ese sentido, en Tumaco hubo serias dificultades para desarrollar Consejos Comunitarios en zonas clave para la dinámica palmera y aquellas fuertemente impactadas por el conflicto armado debido a la presión que estos actores ejercieron sobre el proceso mismo de titulación (Hoffman, 1999).

Posteriormente, aunque en algunas zonas del Mira y del norte y centro del municipio se dieron titulaciones colectivas, la situación se tornó más complicada con la entrada de los actores armados, quienes empezaron a torpedear los procesos organizativos ${ }^{20}$ a través de amenazas, así como el exilio y homicidios de líderes ${ }^{21}$. Esto tuvo como corolario la emergencia de rencillas internas entorno a la conducción del proceso y a los manejos financieros (Entrevistado 7), dando lugar, a comienzos de 2003, a una fragmentación de Palenque Nariño y la posterior fundación de la Red de Consejos Comunitarios del Pacífico Sur - Recompas-, para recomponer el trabajo de base disuelto en las discusiones internas y con el impacto mismo del conflicto armado, especialmente, para aquel momento, de los paramilitares.

20 Recordemos pues que en este periodo se da el asesinato de varios líderes de los consejos comunitarios del Alto y Bajo Mira, amenazas a otros dirigentes y el asesinato de la hermana Yolanda Cerón en 2001.

21 En entrevista con una exparticipante del proceso de Palenque y hoy miembro del PCN en Tumaco, nos expresaba que esta situación en la que los diferentes dirigentes que enarbolaron todo el proceso de titulación en sus territorios empiezan a ser amenazados y asesinados, algunos aprovecharon este "vacío de poder" para denigrar de ellos y así hacerse con la conducción del proceso. 
Con las dificultades del caso, el proceso se ha concentrado en mayor medida en hacer socioeconómicamente sostenible el proyecto de los Consejos Comunitarios y brindar cierto tipo de soluciones a la gente ante las dificultades de gobernabilidad del territorio a cuenta del conflicto armado y de los problemas internos de legitimidad, burocratización y arraigo y conexión de los dirigentes y las lógicas locales.

En síntesis, los Consejos Comunitarios son una figura organizacional ambigua (Oslender, 2007) que brinda nuevas oportunidades de expresión política autónoma dentro de una legislación que por primera vez reconoce los derechos - y obligaciones - a la tierra; pero en dicho proceso de reconocimiento, los territorios se encuentran mediados o atravesados no solo por las diferentes agencias del Estado (Oslender, 2007), sino también por intereses económicos legales e ilegales y las lógicas del conflicto armado, factores que resultan claves para entender el impacto y desarrollo diferenciado de los Consejos Comunitarios en Tumaco.

\section{Organizaciones comunitarias y guerrilla. Más allá de la sumisión y maleabilidad. 1984-2015}

Como resaltamos al inicio, la forma en que se insertaron las lógicas y dinámicas del conflicto armado en Tumaco y el Pacífico nariñense se diferencia de otras regiones porque esta área no fue inicialmente estratégica ni estuvo ligada a las problemáticas y tensiones del mundo andino que dieron origen al actual conflicto armado; es decir, su origen no es endógeno y se explica más por los desenlaces y las apuestas estratégicas de los actores armados en la escala nacional. Así, nuestra posición contrasta con la de quienes atribuyen que las causas de la violencia en la región son producto únicamente del olvido histórico, la corrupción y la clase política local, ya que estos factores son anteriores a la inserción del conflicto armado y, además, difícilmente logran explicar los factores desencadenantes y la persistencia de la violencia política en el Pacífico nariñense (Rodríguez, 2015; Benavides, 2016). 
En ese sentido, la tardía inserción del conflicto armado se debió a dos hechos: (1) los fallidos diálogos del Caguán y la recuperación militar de la zona despejada, que redundaron en que las Farc-EP desplazaran su pie de fuerza para evadir la presión militar; y (2) como resultado del anterior evento, la administración de Uribe no solo continuó la apuesta de recuperación militar sino que la profundizó, lo cual generó el desplazamiento y fortalecimiento de esta guerrilla en esta zona del país (Aponte y Benavides, 2016).

Por otro lado, si bien las Farc-EP se enfrentaron con otros actores que le cuestionaron su control territorial, dígase Estado, paramilitares o GAPD (Anexos: Gráficas 5, 6 y 7), lo cual generó importantes oleadas de violencia, resulta de vital importancia preguntarse el porqué de su éxito en la zona y por su capacidad adaptación y acomodamiento a las diversas dinámicas y procesos que han tenido lugar en el tiempo y espacio en el área de estudio. Una pista que rastrea este artículo es que esta posibilidad se ha visto en gran parte habilitada por su capacidad de incidencia en espacios de la vida comunitaria -casi siempre por medio de las armas-, regulando la vida cotidiana de los pobladores, la forma de hacer política y su articulación con el nivel municipal, regional y nacional. En esta medida, este apartado se centra en la relación e influencia de esta guerrilla sobre dichos ámbitos ${ }^{22}$.

Así, los aspectos que nos interesa explorar para mostrar de qué manera las apuestas militares y políticas de esta guerrilla han afectado

22 En cuanto a la relación entre guerrilla y población civil nos distanciamos de las dos explicaciones clásicas por considerarlas insuficientes: tanto aquellas que aluden a que esta relación atravesada por la coacción y la represión armada, deja a las comunidades en un papel de sometimiento extremo, minimizando su agencia; como también de aquellas que ven en esta relación la construcción de un "poder dual” -o un contrapoder- que disputa la jurisdicción del Estado (Aguilera, 2014). Dichas posicione obvian, como se ha dicho, el carácter dinámico de esta relación en el tiempo y, sobre todo, se desprenden de las particularidades regionales de cada experiencia de inserción guerrillera. 
el contexto local, tornándolo en extremo complejo, son: la forma y los motivantes de su inserción tardía, el desarrollo de sus estructuras armadas y la relación que entablaron con los poderes, las organizaciones sociales y los pobladores locales ${ }^{23}$. Tal es el caso de la contraposición del modelo étnico territorial vs. las juntas de colonos, donde se contraponen diversas jurisdicciones, ideas de desarrollo, de organización y formas de hacer e incidir políticamente.

\section{Génesis guerrillera: de área de refugio a zona estratégica, 1984-1996.}

La inserción de las Farc-EP al Pacífico nariñense se ciñe, al igual que en muchas otras zonas del territorio nacional, a su Séptima Conferencia. Originalmente, incursionaron por medio del Frente VIII ${ }^{24}$, desde la región andina del vecino departamento del Cauca, en un típico movimiento expansivo apalancado desde las zonas interiores del país (Agudelo, 2001). Al inicio se instalaron en el norte de Nariño (1983-1984), para luego extenderse por la zona del piedemonte hasta el litoral pacífico utilizando los ríos Patía, Telembí y el Mira (Rodríguez, 2015; Vicepresidencia, 2009): primero consolidaron su presencia en el piedemonte nariñense ${ }^{25}$ y luego se expandieron al valle del río Guaitira, los municipios de la Costa y el piedemonte $\operatorname{sur}^{26}$.

23 Se parte de la idea de que la relación entre Farc-EP y población civil no es en ningún momento plana y lineal, sino de encuentros y desencuentros en los que estos se topan, cooperan o se enfrentan; algo que a todas luces contribuye a entender las posibilidades y limitaciones que tienen los pobladores tumaqueños y sus organizaciones sociales para incidir en la política local frente a un eventual contexto de posconflicto.

24 Este frente hace parte del Comando Conjunto Central de Occidente o el Bloque Occidental, el cual está compuesto por los Frentes VI, VIII, XXIX, XXX y LX.

25 Principalmente en los municipios de Leiva, La Llanada, Sotomayor, Policarpa, Cumbitara y Barbacoas.

26 Acá están presentes los municipios de El Rosario, Mallama, Olaya Herera, Ricaurte, Samananiego, Sandoná, Mercaderes y Tumaco. 
Inicialmente la presencia de las Farc-EP no representó grandes niveles de confrontación con el Estado u otras fuerzas, ya que esta zona era utilizada más como punto de tránsito y de reposo que como territorios estratégicos militares o de extracción de recursos (Vicepresidencia, 2009; Agudelo, 2001 y 2005). De ahí la poca actividad militar que se registró entre 1991 y 1996 (Echandía, 1998) en contraste con otras regiones del país y su denominativo de "remanso de paz" en medio de la guerra.

Lo anterior no significó que los grupos armados no incidieran en la vida comunitaria y política de las zonas donde tenían presencia. Las Farc-EP intentaron influir en las instancias políticas de los gobiernos locales; aprovechando la debilidad institucional terciaron y dieron trámite a conflictos por tierras o entre familias; y realizaron foros y asambleas en las que remarcaban el abandono estatal y su despreocupación por la gente $^{27}$ (García, 2011).

De esta manera buscaron articular su discurso político general ${ }^{28}$ con el de las poblaciones locales ${ }^{29}$. No obstante, los cortocircuitos fueron evidentes, no solo porque esta guerrilla desconocía las problemáticas históricas (Agudelo, 2005), sino también porque se dedicó a replicar la experiencia colona de zonas del sur del país sin tener en cuenta las particularidades del territorio. Por este motivo desconocieron o desacreditaron a las autoridades tradicionales, hecho que impidió crear unos lazos orgánicos y estables y que, a la postre, explica las limitaciones en su capacidad de reclutamiento y control territorial, pues sus acciones estuvieron siempre ligadas al poder de las armas (Agudelo, 2005 y 2001).

27 Por ejemplo, el Frente XXIX logró tener influencia política en diversas localidades en las que hizo presencia de la mano de actores del movimiento cívico, tuvo una participación representativa en el poder local por medio de la Unión Patriótica $\mathrm{UP}$ - . Por ejemplo la lucha de clases, la necesidad de una revolución para cambiar la idea de Estado y sociedad o la necesidad de una reforma agraria, etc.

29 Para el caso de las comunidades negras: la discriminación racial, la recuperación de la memoria esclavista, valoración de la cultura propia, el derecho a la tierra, etc. 
En efecto, esta es la génesis de las tensiones entre las Farc-EP y los Consejos Comunitarios. No obstante, durante este periodo no se produjo ningún punto de inflexión, pues ni las Farc habían iniciado una extracción de recursos sistemática ni sus comandantes habían sido relevados, por lo cual el lado militarista no se mostraba tan marcado (Anexos: Gráficas 5, 6 y 7).

\section{Del remanso de paz a la integración a las lógicas y dinámicas nacionales del conflicto armado, 1997-2007}

El año de 1997 marcó un punto de quiebre, ya que las Farc-EP apostaron por aumentar su asedio y presión militar sobre diversas áreas del territorio nacional; hecho que tuvo su correlato en Tumaco y la región: se produjo la toma del casco urbano de Ricaurte por parte del Frente XXIX y la toma del Cerro de Patascoy ${ }^{30}$ (Anexos: Gráficas 5, 6 y 7), en los límites de Nariño y Putumayo (García, 2011; Vázquez, Vargas y Restrepo, 2011; Aponte y Benavides, 2016; Rodríguez, 2015). De ese momento en adelante, Tumaco se fue insertando de forma gradual y sostenida a la geografía nacional de la guerra, tanto por los recursos a disposición como por su ventajosa ubicación.

Dicha tendencia se confirmó con el fracaso de los diálogos del Caguán y con el intento del Estado de retomar el control militar del área despejada. Así, las Farc reforzaron su presencia en el Pacífico nariñense y Tumaco para evadir la presión militar y con el objeto de consolidar corredores de movilidad desde Caquetá, pasando por el Huila, Tolima, Cauca y Nariño ${ }^{31}$ (Vicepresidencia, 2009; Agudelo, 2005, Vásquez, 2015; González, Bolívar y Vásquez, 2003). Esto se dio como respuesta a la

En este hecho veintidós soldados resultaron muertos y dieciocho tomados como prisioneros de guerra.

31 Uno de los corredores era el que buscaba conectar el departamento del Caquetá con la costa del Pacífico nariñense, atravesando los departamentos de Huila, Tolima y Cauca. Y otro, que no se materializó, iría a lo largo de toda la región del 
pérdida de presencia y acceso al mar de las Farc-EP en el golfo de Urabá con el avance paramilitar en esta zona del país (García, 2011; Suárez, 2007: Ronderos, 2014). En este orden de ideas y como consecuencia de lo expuesto, en el 2002 se conformaron las Columnas Daniel Aldana y Mariscal Sucre.

Este reposicionamiento no solo residió en consideraciones militares, también les permitió concatenar los diversos eslabones de la coca al darse el traslado de los cultivos de otras zonas del país ${ }^{32}$ por las campañas de fumigación (Vásquez, Vargas y Restrepo, 2011; Torres, 2012) (Gráfica 2). Igualmente, esta ascendencia en el plano militar se tradujo en mayores pretensiones de la guerrilla de incidir en la vida política tumaqueña bajo una directriz concreta: interceder y "controlar" activamente la vida política local haciendo rendir cuentas a los gobernantes e interviniendo en la pasada contienda electoral ${ }^{33}$ (García, 2011).

\section{Gráfica 3}

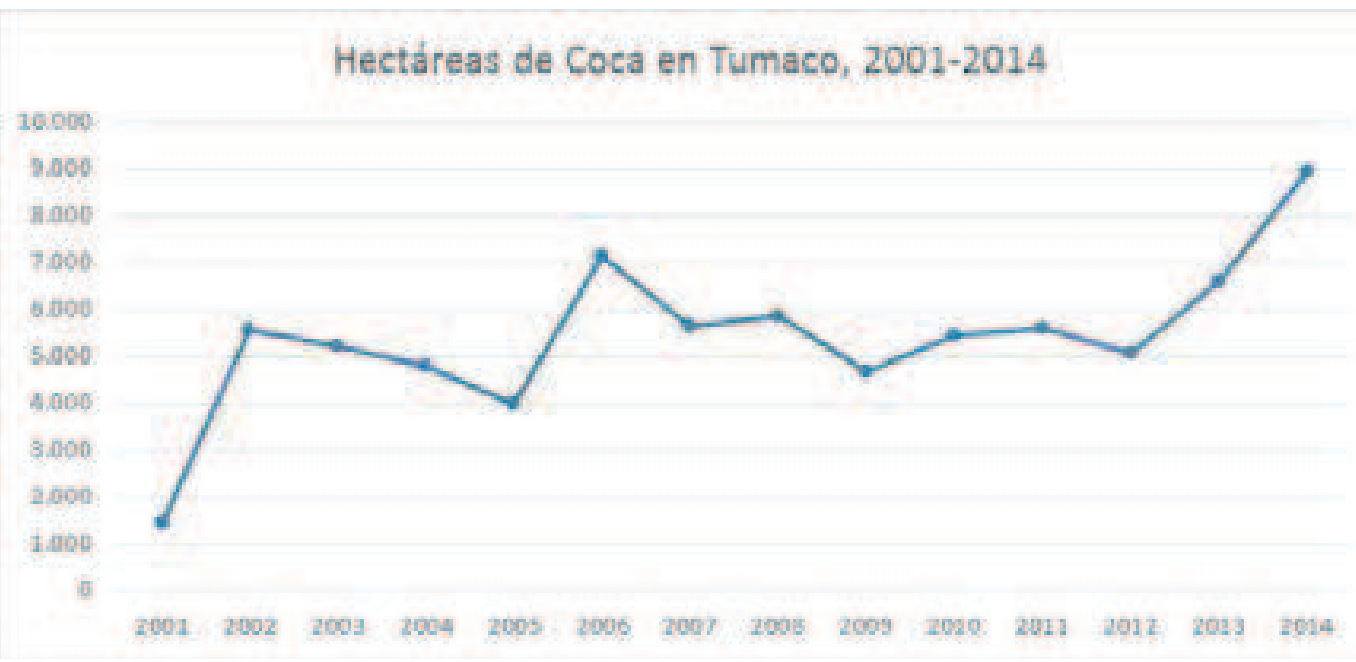

Fuente: Simci. Elaboración propia

Pacífico, desde el Urabá hasta Tumaco, pasando por los puertos de Buenaventura y Guapi en el Cauca y el Valle del Cauca.

32 Guaviare, Meta, Caquetá y, especialmente, Putumayo.

33 Las Farc pretendieron que los diversos políticos aspirantes y electos "representaran" sus intereses y visiones de sociedad. No en vano, una representante por la 
Esta actitud de las Farc-EP a la ofensiva les significó la intensificación de recursos obtenidos de extorsiones y secuestros y la puesta en marcha de acciones que torpedearon la vida cotidiana de la población en general, como por ejemplo bloqueos de la carretera Pasto-Tumaco, y sobre todo de las élites económicas locales (comerciantes y palmeros). La guerrilla culpó a los comerciantes del poco éxito de las movilizaciones locales, por lo cual puso un mayor énfasis en el lado militar de la organización. Esto coincidió con la llegada de nuevos comandantes que acentuaron el ala militarista (Rodríguez, 2015). Todo lo anterior no solo rompió con los débiles "acumulados históricos", sino que también explica la invitación que hicieron tanto los comerciantes como los palmeros a la entrada del proyecto paramilitar en la región, a lo que se sumó una reacomodamiento del narcotráfico en la zona (CNMH, 2016) (Anexos: Gráficas 5, 6 y 7).

Aunque se trata de un asunto en discusión, la llegada del paramilitarismo al Pacífico nariñense, y en específico a Tumaco, se ha intentado explicar cómo una reacción de élites vulnerables que "queriendo acabar un mal terminaron trayendo uno peor”, como afirmó un entrevistado a Rodríguez (2015, p.49). Esta idea enfatiza en la perspectiva contrainsurgente del proyecto paramilitar, pero obvia los reacomodos y nuevos incentivos del narcotráfico en la región.

En ese orden de ideas y superando el antagonismo no muy realista entre política-criminalidad, es decir, más allá de la discusión entre si el proyecto paramilitar en el Pacífico nariñense fue contrainsurgente o simplemente motivado por el narcotráfico, sugerimos como elemento fundamental comprender que la experiencia 'para' en el territorio encontró un terreno fértil que coayudó a su inserción y expansión, caracterizado por

circunscripción especial de Comunidades Negras denunció al Frente XXIX de las Farc por retener más de cuarenta personas, entre ellas alcaldes, concejales y candidatos a diversas corporaciones públicas, para supuestamente incidir en las elecciones locales de finales de octubre de ese año. 
uno factores de tipo estructural y de la vida sociopolítica tumaqueña (i a iii) y otros factores más coyunturales, que involucran igualmente decisiones de los actores (iv y v):

i) Las ventajas geográficas que brinda la zona: esteros, manglares y zonas de difícil acceso permiten la expansión de la siembra y el establecimiento de plantas de procesamiento.

ii) La existencia de rutas a causa de una tradición de contrabando, economías sumergidas y otras prácticas ilegales, las cuales fueron aprovechadas (Laurent, 2008, p.74; Vargas, 2003).

iii) Una precaria presencia estatal y un vacío de poder que es llenado por el poder privado con un manejo patrimonial y personalista, que tiene además conexiones con actividades ilegales, específicamente con el Cartel de Cali.

iv) El asedio de la guerrilla de las Farc-EP a comerciantes y élites locales.

v) La transformación de la economía cocalera en la región, ya que al iniciar su auge el Cartel de Cali es golpeado contundentemente, lo que rompe con el monopolio de esta estructura sobre la zona y abre las posibilidades a nuevos competidores en la disputa por el negocio (Vásquez, Vargas y Restrepo, 2011;Vargas, 2003).

Así, el Bloque Libertadores del Sur ${ }^{34}$ entró a disputarle el control territorial y la regulación sobre los diversos eslabones de la coca a la guerrilla $^{35}$. El arribo paramilitar (1999), que inicialmente hizo presencia en Tumaco y la zona de la carretera que comunica este municipio con Pasto, se expresó, al igual que en otras zonas del país, en la elaboración de listas negras de supuestos colaboradores de la guerrilla, así como en algunas acciones de "limpieza social" y el consiguiente desplazamiento

Es decir, con cultivos, laboratorios, rutas y puertos de embarque para el mercado internacional. Esto tuvo que ver, según Castaño, con una estrategia nacional que buscó acabar con la insurgencia en Colombia, sobre todo la de las Farc-EP, por lo que era necesario quitarles el control sobre su principal fuente de recursos: la coca (González et. al., 2011; Aponte, 2015). 
de la población (Tabla 1 y Anexos: Tabla 3 y Gráficas 5, 6 y 7). Se registró entonces un nuevo punto de inflexión, pues la disputa por el control territorial en Tumaco y el Pacífico nariñense, facilitada por una precaria presencia estatal, estuvo ligada al control y un orden de extracción de los recursos a disposición (García, 2011; Agudelo, 2005; Vicepresidencia, 2009).

\section{Tabla 2. Comparativo de Acciones bélicas e Infracciones al DIH entre actores armados.}

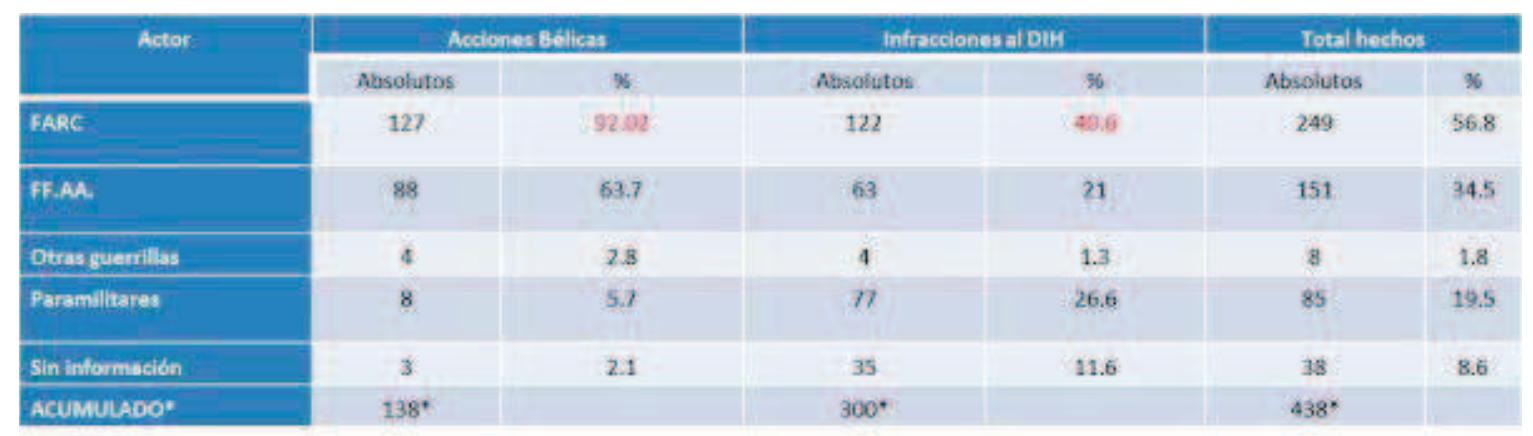

Fuente: Cinep. Elaboración propia

Ahora, sin duda alguna estas disputas territoriales afectaron el proceso organizativo de las comunidades y aplicabilidad de la Ley 70 de 1993, pues no solo se expandieron los cultivos de coca (Gráfica 2), sino que también se dieron procesos de desplazamiento, victimización de los habitantes y limitaciones de movilidad (Anexos: Tabla 3). Igualmente, se afectó la constitución de los Concejos Comunitarios, se retardaron los procesos de titulación, se alteraron las formas de producción tradicionales, etc. (Vicepresidencia, 2009; Aponte y Benavides, 2015). En suma, para estos años emerge un nuevo orden social derivado del cambio en la estructura de propiedad de la tierra, de la presencia del conflicto y de la articulación de los actores armados con la coca (García, 2011; Aponte y Benavides, 2016).

Por otro lado, la introducción de los cultivos de coca se dio de forma contingente y no prevista por cuenta de la campaña de erradicación (Plan Colombia), lo cual incentivó el traslado de los cultivos y, con ellos, la 
migración de contingentes poblacionales ligados a esta economía (Rodríguez, 2015; Vásquez, 2011; Aponte y Benavides, 2016). Inicialmente, estos cultivos fueron introducidos a la región por los ríos Patía y Telembí y a Tumaco por la parte alta del Mira y sus afluentes. Al cabo de un par de años se asentaron de forma consistente en todos los municipios del Pacífico nariñense hasta el sur del departamento del Cauca (Vicepresidencia, 2009). De ahí la configuración de un clúster ${ }^{36}$ y una ventana de oportunidad para que las Farc-EP fortalecieran su aparato armado y ganaran "el apoyo" de ciertos pobladores hacia su organización (Rodríguez, 2015).

La importancia de este suceso radica en que no solo se alteraron las formas de consumo, sino que más importante aún fue el cambio en los patrones de apropiación territorial, pues se empezó a generar una tensión entre los territorios colectivos y los campesinos colono-cocaleros ${ }^{37}$ por la compra por parte de los segundo de predios individuales en los territorios colectivos que estaban en proceso de titulación (Vicepresidencia, 2009). Esto no solo cuestionaba la unidad de las comunidades, también empezó a plantear problemas jurídicos por la carácter "ilegal" de estas ventas. De ahí en adelante se registraron conflictos entre los nativos que habían vendido y aquellos que no lo hicieron, y entre los extraños que compraron o arrendaron con aquellos que no lo han hecho (Vicepresidencia, 2009).

36 Las ventajas geográficas del territorio y la introducción de laboratorios y cristalizadores que permitían el rápido embarque del cargamento hacia el mercado internacional por la gran cantidad de afluentes que desembocan en el mar pacífico explican su configuración.

$37 \quad$ La llegada de estos contingentes poblacionales se vio impulsado por dos elementos que se reforzaron mutuamente. Por un lado, tuvo lugar el retorno de nativos migrantes que se habían vinculado con anterioridad a ciertos eslabones de la economía de la coca (en Guaviare, Putumayo, entre otras zonas), bien sea como cultivadores o como raspachines, recolectores de hoja, etc. Y por otro, se produjo la llegada de comerciantes que incentivaron los cultivos al repartir semillas, financiarlos y garantizar la compra del producto (Vicepresidencia, 2009). 
Estos cambios y dinámicas evidenciaron que la coca llegó para quedarse y que, si bien no todos los pobladores cambiaron de cultivos porque quisieron - el influjo de las armas fue importante-, hubo condiciones estructurales que facilitaron la difusión y consolidación de la coca; hecho que se reforzó porque los programas de sustitución (tanto del gobierno como de las ONG) no correspondían a las tradiciones productivas y de consumo de los pobladores o porque los programas promovidos, como el cultivo de cacao, no contaban con la infraestructura necesaria ni un mercado estable. Esta situación contrasta notablemente con la coca, pues se tiene acceso fácilmente a las semillas, a los insumos y la demanda garantiza la compra del producto (Vicepresidencia, 2009; Aponte y Benavides, 2016).

De ahí que no deba extrañar que las Farc-EP lograran un mayor juego en la vida comunitaria y política: en las zonas rurales establecieron un régimen contributivo, el cual manejaban a su parecer ${ }^{38}$ (Vicepresidencia, 2009); influyeron y obstaculizaron ciertos procesos organizativos al interceder en la dinámica de los Consejos; e impusieron ciertas normas y parámetros de regulación ${ }^{39}$. Pero esto no es todo, pues como estrategia paralela de erosión y desconocimiento de los Consejos Comunitarios impulsaron procesos organizativos paralelos no integrados por nativos, como las asociaciones de los ríos Mira, Nulpe y Mataje (Vicepresidencia, 2009; Aponte y Benavides, 2016).

38 Por ejemplo, con los fondos recaudados una comunidad les propuso que destinaran el 50 \% del recaudo para vías, escuelas y otras necesidades, pero la agrupación se negó argumentando necesidades militares. También intentaron poner en la dirección de estos procesos a personas afines o simplemente desconocieron la potestad de las Juntas de los Consejos Comunitarios (Aponte y Benavides, 2015).

39 Tal es el caso de las Farc-EP en las zonas del Alto Mira, el Nulpe, el Mataje, la Balsa y Palamí. Su presión sobre las autoridades llevó a que estas dejaran de reunirse e incluso alguno se vieron en el a necesidad de desplazarse. Pero las Farc-EP no fue la única organización, también los paramilitares desplazaron varios líderes comunitarios y dirigentes que decidieron abandonar la región por la difusión de listas negras (Agudelo, 2001). 


\section{El continuismo 'fariano': la organización social entre las armas y la política, 2007-2015}

Las dinámicas anteriormente descritas se acentuaron en los últimos años debido a los siguientes factores: (1) el proyecto paramilitar, al igual que en otras zonas del país (Catatumbo, Sucre, Valle del Cauca, etc.), solo logró establecer y consolidar su presencia en el casco urbano y en el corregimiento de Llorente, pero nunca tuvo la posibilidad de regular y ni siquiera insertarse en los espacios rurales ${ }^{40}$ (Aponte, 2012 y 2015; CNMH, 2014; Rodríguez, 2015); (2) el control 'fariano' en la parte rural fue poco cuestionado y se afianzó con el tiempo; y (3) con la desmovilización de las AUC tuvo lugar un proceso de rearme materializado en el ingreso de las Águilas Negras y los Rastrojos, pero estos grupos no lograron asentarse en el territorio por su forma de actuar, lo cual terminó desgastando su relación con los pobladores locales (Entrevistado 1 y 2 ).

En este orden de ideas, estos factores le permitieron a la guerrilla recuperar sus espacios perdidos y regresar a las partes urbanas de Llorente y, sobre todo, Tumaco y consolidar su presencia en lo rural. Lo anterior estuvo enmarcado en la Operación "Renacer" (Entrevistado 2; Rodríguez, 2015; CNMH, 2014a), la cual significó un aumento exponencial de la responsabilidad de esta guerrilla en violaciones al DIH y acciones bélicas, como puede verse en la Tabla 1 .

Se profundizaron entonces las tensiones generadas por la colonización campesino-cocalera, enmarcada en este afianzamiento 'fariano', ya que fue apuntalando sus propios mecanismos de regulación en contraposición a las formas tradicionales de los Consejos. ¿En qué

Si se estudian y analizan otros casos del territorio nacional, se hace evidente la imperiosa presencia de una sociedad sedimentada y jerarquizada de forma clara para que los paramilitares puedan no solo insertarse exitosamente sino también imponer un orden y control territorial (CNMH, 2016; Gutiérrez y Barón, 2006). 
consistió la situación?, ¿cuáles han sido las estrategias? y ¿cómo se ha visto afectada la organización social?

En el ámbito político, las Farc-EP continuaron impartiendo "la cátedra bolivariana, pues las otras formas de desarrollo disque hacen parte de la dominación y que la deben dejar por eso, así se han opuesto a Recompas" (Entrevistado 3). También se inmiscuyeron en los asuntos internos de los Consejos, como los mecanismos de democracia interna y el derecho a denunciar. Igualmente, hay quienes dicen que presionaron a la gente a marchar so pena de recibir una multa de 500.000 pesos si no lo hacían ${ }^{41}$ y que se encargaban de impartir justicia en algunas situaciones; por ejemplo, "si robas una ganilla, te matan, te destierran o cortan la mano" 42 (Entrevistado 4).

Esto no quiere decir que la presencia 'fariana' haya sido homogénea en todo el territorio. Por el contrario, esta se ubicaba principalmente en la zona rural (Alto Mira y Frontera), en la cabecera municipal y sobre el eje de la carretera de Pasto-Tumaco, no solo a cuenta de una menor presencia de la Fuerza Pública, sino también porque es en estos lugares está su base social. De ahí su intención de influir por medio de las armas en los Consejos Comunitarios al tomarse "la vocería en temas sensibles, como la salud". Este hecho se vio facilitado por "los diálogos de la Habana, [porque] ellos nunca han tenido lo que se llama el apoyo de la sociedad civil. Ellos crearon unas Juntas con sus líderes formados por ellos y los sacan a la calle a protestar, sobre todo en la zona de carretera: Guayacana y Llorente” (Entrevistados 6 y 8).

Pareciera ser que esta estrategia y apuesta de injerencia de la vida política local y sub-local, estaba enmarcada en las apuestas políticas de

${ }^{41}$ Este entrevistado dijo que esta fue una de las órdenes del grupo armado para el reciente Paro Agrario Nacional.

42 Si bien consideramos que esta expresión puede ser exagerada, sí da cuenta de las formas y capacidades de regulación de las Farc en este zona del país. 
las Farc-EP de cara a su futura desmovilización e inclusión al juego democrático. Este aspecto ha generado una percepción de "preocupación porque los Concejos han visto su autonomía recortada. Algunas autoridades sostienen que se vienen presentando casos de presión y de uso de vías de hecho, para hacer marchas y bloqueos (Entrevistado 6). Y esta estrategia se intensificó por el contexto electoral y su posible desmovilización, están impulsando sus candidatos en la parte rural para concejo, alcaldías, asambleas" (Entrevistados 6 y 8).

La anterior cita revela la magnitud y dimensión de su influencia, pero también las posibilidades de los pobladores locales frente al grupo armado. Sin duda alguna, la zona rural es la de mayor influencia 'fariana' al ordenar y regular varios aspectos de la vida comunitaria, lo cual adquirió un viso de normalidad: “quien más regula a la población es las Farc. Esto es considerado lo más normal. [Por eso] el Concejo Comunitario tiene que disputarle la resolución y trámites de los conflictos locales" (Entrevistado 3). Igualmente, establecieron controles al desplazamiento de las personas: en algunos Consejos sus miembros les tenían que pedir permiso "para la entrada de plata, para apoyar un político, salir de la zona, etc.” (Entrevistados 5 y 8).

Pero esta capacidad de "regulación" en el escenario rural (veredas y corregimientos) se torna porosa de acuerdo a los pobladores y el tipo de organización presente. Así, las comunidades que tienen una mayor tradición de organización y una estructura más sedimentada tuvieron mayor capacidad de resistir y negociar; hecho que matiza la idea de que todos los pobladores locales iban al vaivén de las directrices 'farianas' o que todas las organizaciones sociales son producto de las Farc-EP. Algunos Consejos lograron adaptarse, negociar y mantener cierto margen de maniobra al fragor de las armas, logrando acomodarse o negociando las directrices impuestas:

los miembros [del Consejo]) no siguen al pie de la letra las órdenes, hay una reticencia, se les enfrentan porque ellos no son mandaderos. Una vez 
montaron dos presidentes. Uno está muerto y el otro preso, la gente le toca acomodarse por la intimidación de las armas. Lo que quiero mostrar es que el dominio del territorio de las Farc no quiere decir que dominan la política y los procesos organizativos o los Consejos. (Entrevistado 3)

En efecto, para los Consejos Comunitarios hay temas que entran en lo no negociable, como el medio ambiente o la educación: "Puede que las Farc tengan injerencia en algunas vainas, pero (...) el tema ambiental entra en lo no negociable, pero en algunas otras zonas sí; se meten en temas de los problemas familiares, el tema de los linderos, etc. (...) eso depende mucho de la zona, del Consejo, etc.” (Entrevistados 3 y 8).

Estos matices, capacidades de contestación y negociación de las comunidades locales no solo muestran la imposibilidad de este grupo armado para incidir plenamente en todos los ámbitos de la vida cotidiana y de consolidar una verdadera base social; también dan cuenta de las relaciones complejas que se entretejen entre guerrilla y población y, en cierta medida, explican por qué las Farc-EP debía recurrir a los sectores de los colonos cocaleros.

No por nada, impulsaron procesos organizativos paralelos buscando aprovechar las vicisitudes, burocratización y pérdida de impulso reciente de los Consejos Comunitarios y, de paso, arrebatarles el monopolio de la interlocución con el Estado en todas sus escalas y con las agencias de cooperación. Ahora, lo interesante de este asunto es que la estrategia guerrillera ha hecho uso de la institucionalidad: a través de las JAC han promovido nuevas formas de apropiación territorial y de desarrollo rural que terminan por contraponer dos modelos de desarrollo, intermediación política, etc. Ahora, ¿cuál es la estrategia ycómo la han desarrollado?

Para uno de los entrevistados, las Farc-EP han utilizado esta estrategia por su imposibilidad de incidir en los Consejos Comunitarios (Entrevistado 4), pues se ha respaldado en las armas y ha creado fuertes 
tensiones con estos. Pero lo más grave es que la idea de propiedad de ambos no solo es distinta sino que ha afectado la misma territorialidad de los Consejos y sus jurisdicciones a raíz de la compra individual en detrimento de la propiedad colectiva (Entrevistados 5 y 8).

Así, al tradicional binomio identificado por González, Bolívar y Vásquez (2003), que contrapone el modelo de desarrollo rural impulsado por los paramilitares con el de las Farc- $\mathrm{EP}^{43}$, se le ha sumado, en este contexto local, una nueva contraposición: la del modelo de desarrollo rural étnico institucionalizado ${ }^{44}$ basado en la propiedad colectiva versus la economía campesina colonococalera de propiedad individual. Esta situación se refleja en que "las dos poblaciones [tanto colonos como afros], por su lado, exigen sus derechos de propiedad" (Entrevistado 6). Así, estos "dos tipos de propiedad reconocidas por el Estado, generan, (...) sin duda alguna, un conflicto específico. Volviendo el tema una cuestión sensible en el ámbito local” (Entrevistado 3).

En esta vía, consideramos que estas nuevas dinámicas y procesos complejizan en extremo un escenario que de por sí ya tenía diversos ingredientes y componentes. La compleja y variopinta legislación que reconoce distintas jurisdicciones y formas de apropiación territorial ${ }^{45}$ complejiza las tensiones por la forma de entender y organizar el territorio. A esto se le suman las tensiones generadas entre autoridades tradicionales y la

43 En el primero, se promueve e impulsa un modelo de desarrollo rural intensivo y extensivo de la agricultura; mientras que en el segundo se promociona un modelo agrario basado en la pequeña propiedad y la economía campesina.

Que tiene toda una serie de complejidades internas: el mundo de la titulación colectiva de los Consejos Comunitarios no se ha encontrado exento de discusiones en torno al lugar que tiene la propiedad individual en estos territorios, así como el lugar y la reglamentación de los cultivos de palma o las camaroneras allí asentadas. Esto se profundiza con la indecisión institucional, es decir, la ausencia de mecanismos reglamentados por la ley para solucionar este tipo de conflictividades sobre la propiedad y el uso de la tierra en estos territorios.

45 Por ejemplo Consejos Comunitarios, Resguardos Indígenas y Juntas de Acción Comunal y Local. 
nueva institucionalidad representada en los entes organizativos étnicoterritoriales, así como entre los pobladores negros y los propietarios de las plantaciones de palma e, incluso, entre las mismas comunidades que se disputan espacios de poder y representación en el proceso de titulación (Agudelo, 2005; Agier y Hoffmann, 1999).

A todo lo anterior se le agrega además el arribo de narcotraficantes, que igualmente impulsan su idea de región con proyectos mineros, pesqueros y turísticos hacia la zona central (Agudelo, 2001), y la reivindicación de zonas de resguardos indígenas, que también se solapan con los Concejos y las JAC, lo cual genera grandes competencias por la titulación sobre la misma área (Agudelo, 2001). Finalmente, debemos añadir las tensiones entre las JAC y los Consejos.

Por eso, algunos pobladores se han mostrado escépticos frente a los Acuerdos de la Habana porque creen que las Farc-EP no van a dejar de ejercer la justicia que ellos han impuesto y delegarla sobre las comunidades y las autoridades locales (Entrevistado 3); a lo que agregan que el espacio dejado por la guerrilla puede ser copado por otro actor armado, sobre todo teniendo como referente el fallido proceso de desmovilización paramilitar, que, como ya se mencionó, en Tumaco se tradujo en la inserción de las denominadas Águilas Negras y posteriormente los Rastrojos.

En líneas generales, lo resaltado en este apartado da cuenta de que Tumaco cuenta con los componentes necesarios para que un actor paraestatal se apropie de la economía de la coca y, con ello, del control sobre elementos específicos de la vida en el territorio, ya que la coca no solo ha representado una forma de subsistencia para las bases colonas cercanas a las Farc-EP, sino también por la misma condición de la población local. Los índices sociales y económicos hacen que los tumaqueños se enrolen en esta actividad para satisfacer sus necesidades y aspiraciones.

Así, a las causas objetivas hay que sumar la posición estratégica del lugar y el interés de los narcos por el municipio: "Esta zona es una 
zona particular porque es estratégica para el narcotráfico. Ellos, los narcos, van a seguir utilizando las rutas después de la salida de las Farc" (Entrevistado 5). Algo que sin duda planteará un entorno hostil para el proceso de implementación de lo acordado en La Habana y podría conllevar a nuevos ciclos de conflictividades en la zona. Muestra de lo anterior son los recientes sucesos en la región, ya que mientras se firmaba el Acuerdo de paz en La Habana, la situación de seguridad se fue alterando tanto por disidencias de milicianos de las Farc-EP no comprometidos con la desmovilización e interesados en la economía cocalera y cocainera, como por los ajustes de cuentas que ha desarrollado esta organización a los sectores disidentes que cada vez más se van acercando a las estructuras de los grupos posdesmovilización en la zona (La Silla Vacía, 2016 y 2016a).

\section{Conclusiones: la necesidad de una intervención diferenciada en el posconflicto}

El caso de San Andrés de Tumaco refleja cómo una inserción exógena del conflicto armado, por asuntos de tipo estructural (pobreza, marginalidad, etc.), se ha convertido en un elemento estructurante de la vida social y política de la región. Finalmente, para resaltar y concretar algunos de los aspectos ya retratados, y a manera de conclusión, en este apartado se brindan una serie de recomendaciones para la posible acción tanto del Estado central como de organismos de cooperación internacional frente al contexto de posacuerdo y de implementación de lo acordado en La Habana. En este orden de ideas, y teniendo en cuenta los patrones de poblamiento, la forma de hacer y de intermediar en política, el carácter, las posibilidades y los problemas de los pobladores de esta zona, proponemos las recomendaciones expuestas a continuación.

- Atender eficazmente los reciclajes y resquemores de la guerra.

Quizá uno de los asuntos que requiere una intervención inmediata tiene que ver con los asuntos relacionados con la lógica del conflicto 
armado y su impacto en la vida comunitaria, en la organización y la movilización. En primer lugar, es necesario tener en cuenta el desafío que plantean los GAPD y el posible reciclaje de la guerra en Tumaco a causa de algunos legados armados (experiencia armada, vinculación de forma remunerada, conocimiento de todas las cadenas del narcotráfico, etc.); y en segunda instancia —en el plano comunitario-, se deben considerar los posibles revanchismos que se pueden presentar entre comunidades negras y colonos y ex combatientes de las Farc-EP con la firma de la paz.

Allí es fundamental abandonar discursos señaladores que planteen una asociación simple de estos contingentes de colonos con la guerrilla, porque esto no solo puede estigmatizar a estas poblaciones, sino acrecentar la violencia. De lo que se trata entonces es de orientar mecanismos locales de reconciliación que desactiven una posible reacción violenta de las comunidades negras contra estas poblaciones que, de una u otra manera, y a pesar de estar a veces refugiadas bajo las armas, no han hecho parte de la confrontación de manera directa y ya tienen cierta vida en el territorio. En este sentido, es necesario no solo garantizar y clarificar el inestable régimen de propiedad rural existente (Gutiérrez, 2014), sino también sanear e incorporar las nuevas formas de propiedad, así como proteger los resguardos y territorios colectivos ya constituidos.

\section{- Comprender e incorporar el poder local a la institucionalidad.}

En primer lugar, para dilucidar los retos y posibilidades de cara al posconflicto, es fundamental entender la geometría variable del poder en el nivel más local; algo muchas veces olvidado por los agentes externos al territorio (Estado, ONG y hasta las mismas guerrillas en sus intentos de inserción). Esto significa que en el caso de Tumaco, en un espacio como las veredas y corregimientos, hay diversos formas de regulación y de sociabilidad que se encuentran atadas a los procesos de configuración regional, a los territorios colectivos, a ciertas estructuras clientelistas, 
a autoridades más tradicionales y a ordenes sociales construidos por la guerrilla. Es decir, este es un espacio en el que convergen distintas pautas y cánones de comportamiento que deben ser entendidos e incorporados.

Ahora, por lo variopinta que es la sociedad civil tumaqueña, no es posible decir, por ejemplo, que se trata de una serie de actores con lógicas anti-estatales o que son actores homogéneos; por el contrario, hay diferentes expresiones de la sociedad en el ámbito rural y en el ámbito urbano. En ese sentido, construir una nueva instancia o un nuevo mecanismo puede generar traumatismos en esa geometría del poder. Hay que proponer y construir a partir de los acumulados que se tienen, sus diferencias sublocales y sus posibilidades y dificultades en este escenario de transición.

\section{- En el ejercicio de la política, centralizar y promover nuevos liderazgos.}

Uno de los grandes riesgos que corre la implementación de los acuerdos es que los posibles beneficios de los programas del posconflicto se queden en las redes clientelares y en los gamonales de turno. Para ello es fundamental buscar medidas e incentivos que centralicen la inversión social y otros servicios y que promuevan una mayor democratización. En ese sentido, los acuerdos sobre participación política en La Habana abren una ventana de oportunidad y pueden influenciar positivamente a la experiencia de las organizaciones sociales o aquellas lejanas a las lógicas clientelistas en la vida política. Es fundamental rodear su puesta en marcha y ajustar la institucionalidad a las condiciones políticas locales, ya que muchas veces, por diversas coyunturas, estas organizaciones son relegadas del ejercicio y disputa por el poder o se han visto en la necesidad de tranzar con los gamonales tradicionales para tener ciertas posibilidades de éxito; situación que compromete seriamente sus expectativas y objetivos a la hora de gobernar y tener independencia. 


\section{- Revitalizar los Consejos Comunitarios y catapultarlos como actores de la transición.}

El movimiento de las comunidades negras atraviesa por una etapa en la que enfrenta dificultades prácticas por cuenta de su viabilidad como proyecto socioeconómico, los impactos de la guerra, así como por sus debilidades y conflictos internos. No obstante, son el actor de mayor relevancia y agencia sobre el territorio, no solo en cuanto a su gestión sino también como articulador, integrador y organizador de las comunidades. Por esto es fundamental reimpulsar y apuntalar la figura de los Consejos Comunitarios en su poder de gestión, pero también como entidades concretas en el territorio; repolitizar su dinámica en un sentido positivo; y potenciar sus atribuciones administrativas y de resolución de conflictos en el territorio, golpeada por la corrupción, las disputas internas y el conflicto.

\section{- Propiciar canales eficaces, realistas y propositivos de los actores de la sociedad civil.}

Uno de los principales retos de cara a la implementación de lo acordado tiene que ver con propiciar una interlocución mucho más sistemática y concreta entre las autoridades municipales y estas expresiones de la denominada sociedad civil. Es fundamental desligarse de desconfianzas mutuas y entender las organizaciones comunitarias y sociales como la posibilidad de que el Estado llegue más allá de lo militar a estas zonas. Algo que, además de contribuir a las condiciones y abrir la puerta a un proceso democratizador, significa insertar a estas poblaciones rurales y de los ríos, sin que ello signifique una pérdida de sus tradiciones o de sus acumulados históricos.

En esta vía, es necesario potenciar de manera realista mecanismos de coordinación entre las diferentes expresiones de la sociedad civil y su interlocución con el Estado local más allá de lo formal, aprovechando el 
conocimiento, la legitimidad y los acumulados de estos procesos en el territorio. Este es el camino para verdaderamente contribuir en el mejoramiento de la calidad de vida de estas poblaciones, con un gran déficit en cuanto a derechos sociales y económicos y una afectación negativa a cuenta del conflicto armado (Anexos: Gráfica 5 y Tabla 3).

\section{Anexos}

Gráfica 4. Titulación de Baldíos en Tumaco, 1900-2012.

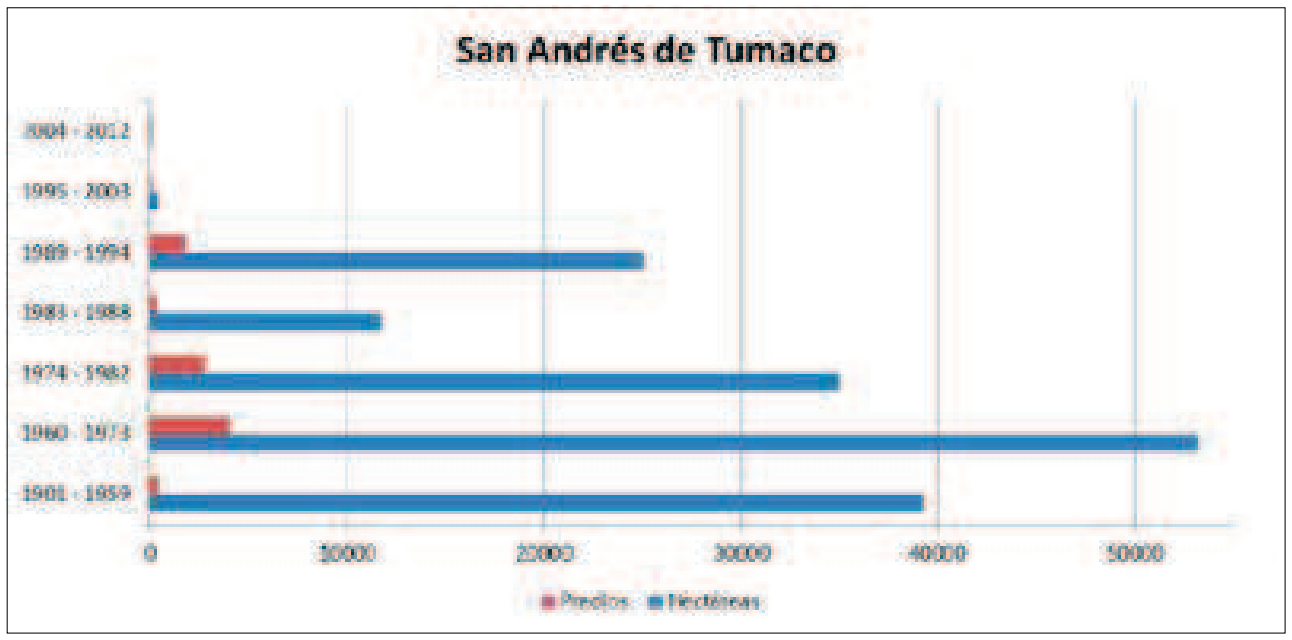

Gráfica 5.

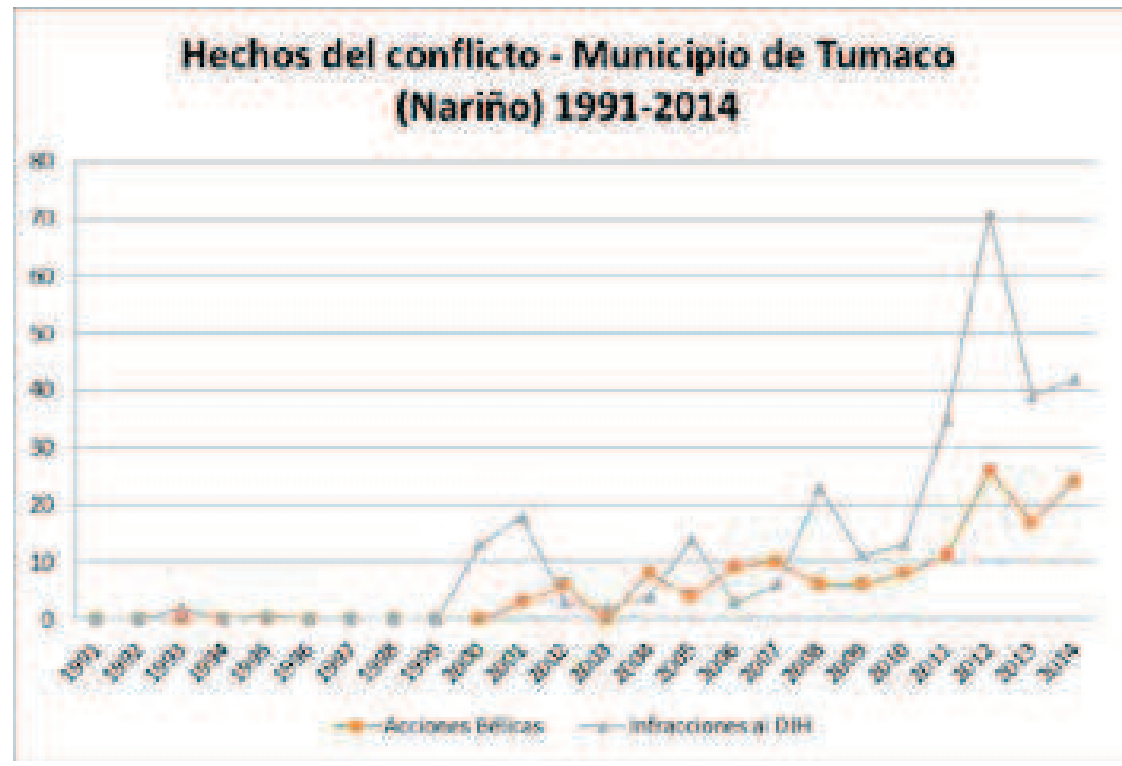

Fuente: SIG-Cinep. Elaboración propia. 
Gráfica 6.

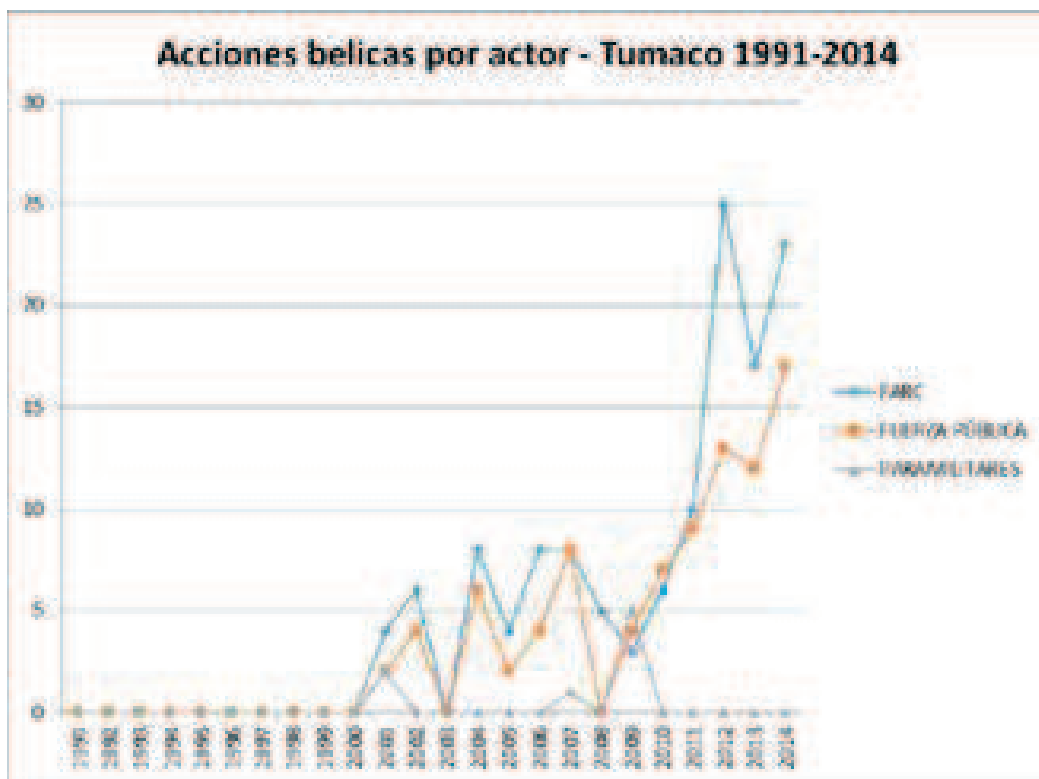

Fuente: SIG-Cinep. Elaboración propia.

\section{Gráfica 7.}

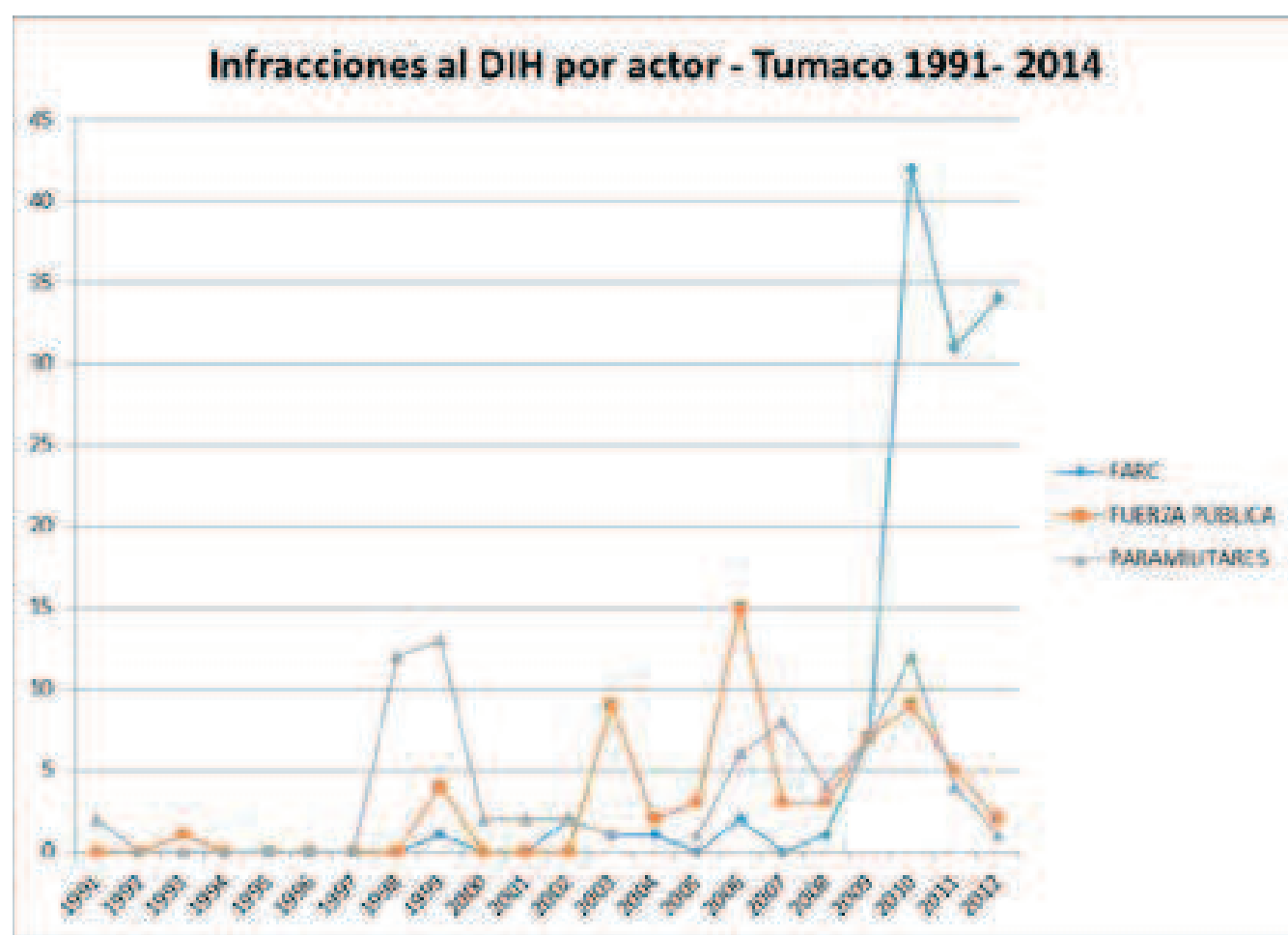

Fuente: SIG-Cinep. Elaboración propia. 
Tabla 3. Desplazamiento por municipios en Nariño, 1999-2015.

\begin{tabular}{|c|c|c|c|c|c|c|c|c|c|c|c|c|c|c|c|c|}
\hline mikiph & 995 & 2000 & 2001 & 2002 : & 2000 & \begin{tabular}{|l|l|l|}
2004 & 2065 \\
\end{tabular} & 2006 & 2007 & 2008 & 2009 : & 20102 & 2011 & 2012 & 2013 & 201 & 2015 \\
\hline les bist & 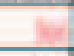 & ty & 난 & 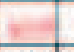 & 0 & $48 \mathrm{mn}$ & 4 & 24 & $a^{2}$ & if & $\operatorname{ans}$ & 26 & Es & $m !$ & 4 & 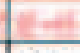 \\
\hline Elantso & 84 & 195 & 1200 & 4386: & 4595 & 5595820 & 939 & 3486 & NG623: & 3005 & 355174 & $411 n$ & 4928 & 4271: & 4317 & $4 y_{03}$ \\
\hline 115 & 202 & 330 & 1531] & 2757 & 3522 & 452267031 & 10453] & 12255 & $174 m ! 1$ & 19740.2 & 21414.2 & $n \times 001$ & 24280 & $25 \times 2$ & 26657 & 2098 \\
\hline olkap & 158 & 200 & 296 & 662 & 1476 & 2280.3267 & 816 & $105 \pi$ & 146661 & 15757.1 & 1674.1 & 1824! & 2020 & 27200 & 2228 & 224 \\
\hline to & 423 & 800 & 146? & 7187 & $\pi 27$ & 8162594 & 920 & 200 & 100421 & 10501.1 & 10643.1 & 1000 & 11454 & unde & 1200 & 121 \\
\hline lava & 45 & 110 & 978 & 1649 & 1336 & $19 \pi \sqrt{2250}$ & $30 \%$ & 397 & $(6,9)$ & $\sec 8$ & 109911 & 11893 & 13216 & 14459 & 15331 & 15. \\
\hline at & 25 & 79) & $39 n$ & 3654 & 3757 & 318405 & 455 & 8916 & $72 \theta$ & $25 \%$ & cost & 803 & 267] & 10162 & 10457 & 249 \\
\hline beto & 40 & 55 & 143 & 30 & 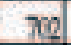 & 8341526 & 1880 & 3172 & 5808 & 6592 & 8314 & $90 m$ & IIIAS & 1180 & 12216 & 125 \\
\hline rikan & 33 & 68 & 101 & 201 & 380 & 697.1043 & 2035 & 8081 & $713:$ & 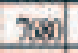 & 8148 & 8983 & 988 & 908 & 10478 & - \\
\hline ning & 83 & 118 & 257 & 504 & 637 & $82 \pi 104$ & $128 \pi$ & 2034 & $288 \pi$ & 6552 & 7357 & $842 x$ & & 1083] & & \\
\hline
\end{tabular}

Fuente: OCHA. Elaboración propia.

\section{Entrevistas}

- Entrevistado 1. Taxista de la ciudad de Tumaco. Realizada en julio 27 de 2015.

- Entrevistado 2. Miembro de Pastoral Social. Realizada en julio 27 de 2015.

- Entrevistado 3. Antiguo miembro de Recompas y experto en temas de Justicia tradicional. Realizada en julio 28 de 2015.

- Entrevistado 4. Abogado local. Realizada en julio 29 de 2015.

- Entrevistado 5. Funcionario de la Unidad para la Atención y Reparación Integral a las Víctimas. Realizada en julio 29 de 2015.

- Entrevistado 6. Secretario de Gobierno del municipio de Tumaco. Realizada en julio 30 de 2015.

- Entrevistado 7. Líder afro. Realizada en octubre 29 de 2015.

- Entrevistado 8. Miembro del Consejo Comunitario del Alto Mira y Frontera. Realizada en octubre 30 de 2015.

- Conversación con líderes de Tumaco, Francisco Pizarro y Barbacoas. Realizada en abril 18 de 2016. 


\section{Bibliografía}

Agudelo, C. E., Hoffman, O., y Rivas, N. (1999). Hacer política en el pacífico Sur: algunas aproximaciones. Documento de Trabajo no. 39. CIDSE. Cali: Universidad del Valle. Recuperado de http://bibliotecavirtual.clacso.org. ar/ar/libros/colombia/cidse/Documento39.pdf

Agudelo, C. (2005). Retos del multiculturalismo en Colombia. Política, inclusión y exclusión de poblaciones negras. IRD, ICANH y IEPRI. Medellín: La carreta editores.

Aguilera, M. (2014). Contrapoder y justicia guerrillera. Fragmentación política y orden insurgente en Colombia (1952-2003). Bogotá: IEPRI, Universidad Nacional de Colombia.

Alcaldía Tumaco. Descripción geográfica del municipio. Recuperado de http:// www.tumaco-narino.gov.co/index.shtml

Aponte, A. (2012). Cúcuta y el Catatumbo: entre la integración y la marginalización. En F. González (ed.). Conflicto y territorio en el Oriente colombiano. Bogotá: Odecofi, Cinep/PPP y Colciencias.

Aponte, A. (2015). Ganaderos, barones regionales y paramilitares: Hacienda, poder y violencia en las Sabanas de Bolívar, 1980-2014 (tesis para obtener el grado de maestro en Sociología General). Escuelas de Altos Estudios en Ciencias Sociales (EHESS), París.

Aponte, A., y Benavides, J. (2015). Entre ríos y coca: organizaciones sociales, territorio y política en Sán Andrés de Tumaco. Documento de trabajo del Proyecto Organizaciones sociales y gobernabilidad local en el posconflicto. Bogotá: Cinep/PPP y Banco Mundial.

Arjona, A., Cárdenas, J. C., Ibáñez, A. M., Justino, P., y Martínez, U. (2015). The legacies of Wartime Institutions on citizens Preferences for the rule of Law. Documento inédito.

Barrera, V. (2016). Potencialidades y limitaciones de las organizaciones sociales de base. Los casos de La Macarena, San Vicente del Caguán y San Andrés de Tumaco. Documento informe para la construcción de paz territorial. Banco Mundial. Documento inédito. 
Benavides, J. (2016). De la crítica de las armas a las armas de la crítica. Acercamiento historiográfico al informe de la CHCV (trabajo de grado para optar por el título de Historiador). Pontifica Universidad Javeriana, Bogotá.

Castillo, L. (2007). Etnicidad y nación. Cali: Universidad del Valle.

Centro Nacional de Memoria Histórica (2014). Patrones y campesinos: tierra, poder y violencia en el Valle del Cauca. 1960-2012. Bogotá: Publicaciones Semana y Taurus.

Centro Nacional de Memoria Histórica. (2014a). Guerrilla y Población Civil. Trayectoria de la Farc 1949-2013. Bogotá: CNMH.

Concejo Municipal de Tumaco. (2013). Acuerdo 019 Por medio del cual se hacen unos ajustes al Plan de Desarrollo de la Administración Municipal de Tumaco 2012-2015. Recuperado de http://www.tumaco-narino.gov.co/ index.shtml?apc $=$ kbxx--1368885\&sh_itm $=82048 b c 2 e c f d b 6 f 98166535 \mathrm{c} 37$ 29d328\&add_disc $=1$

Echandía, C. (1998). Indagación sobre el grado de concentración de la actividad armada en el conflicto interno armado. Bogotá: CEDE, Universidad de los Andes.

García, P. (2011). La paz perdida. Territorios colectivos, palma africana y conflicto armado en el Pacífico colombiano (tesis para obtener el título de Doctora en investigación en Ciencias Sociales con especialización en Ciencia Política). FLACSO.

González, F., Bolívar, I., y Vásquez, T. (2003). Violencia política en Colombia: de la nación fragmentada a la construcción del Estado. Bogotá: Cinep.

González, F. (2014). Poder y violencia en Colombia. Bogotá: Cinep.

González, F., Guzmán, T., y Barrera, V. (2015). Estrategias para la construcción de paz territorial en Colombia. Elementos para la discusión. Documento Ocasional n 79. Bogotá: Cinep.

Fernán González, Dorly Castañeda \& Víctor Barrera (2017). Potencialidades para la paz de las organizaciones sociales y comunitarias en tres municipios afectados por el conflicto armado DO n. ${ }^{\circ} 81$ - Febrero del 2017 Bogotá:CINEP 
González, J. J. (1992). Espacios de exclusión: el estigma de las Repúblicas independientes 1955-1965. Bogotá: Cinep.

Gutiérrez, F. (2014). El Orangután con saco leva. Cien años de democracia y represión en Colombia (1910-2010). Bogotá: IEPRI, Universidad Nacional de Colombia y Debate.

Helfrich-Bernal, L. (2000). Elecciones: entre gamonalismo y civismo. El caso de Tumaco en la costa Pacífica. Territorios (4), 39-51.

Hoffmann, O. (2007). Comunidades negras en el Pacífico colombiano. Innovaciones y dinámicas étnicas. Quito: IFEA-IRD y Ediciones Abya-Yala.

Hoffmann, O. (1999). Sociedades y espacios en el litoral pacífico sur colombiano. En M. Agier, M. Álvarez, O. Hoffmann, y E. Restrepo. Tumaco: ciudad, historia, identidad y cultura (pp.15-53). Bogotá: ICAN, IRD y Universidad del Valle.

Jaramillo, J., Mora, L., y Cubides, F. (1989). Colonización, coca y guerrilla. Bogotá: Alianza Editorial.

Kalyvas, S. (2006). The logic of violence in civil war. Cambridge: Cambridge University Press.

Kaplan, O. 2011. "Civilian Autonomy in Civil War". Doctoral thesis, Stanford: Stanford University.

La Silla Vacía. (31 de octubre de 2016). "Don Y”, el disidente de las Farc que azota a Tumaco. Recuperado de http://lasillavacia.com/historia/don-y-eldisidente-de-las-Farc-que-azota-tumaco-58539

La Silla Vacía. (16 de noviembre de 2016). Las Farc mataron a "Don Y". Recuperado de http://lasillavacia.com/historia/las-Farc-mataron-don-y-58754

Leal León, C. (2005). Un puerto en la selva. Naturaleza y raza en la creación de la ciudad de Tumaco, 1860-1940. En Historia Crítica (30), 39-65.

Mann, M. (1992). Las Fuentes del poder Social. Tomo II. Madrid: Alianza Editorial.

Mann, M. (2006). El poder autónomo del Estado: sus orígenes, mecanismos y resultados. En Revista Académica de Relaciones Internacionales (5). 
Molano, A. (2014). Selva Adentro. Una historia oral de la colonización del Guaviare. Bogotá: Penguin Random House.

Moore, B. Jr. (2002). Los orígenes sociales de la dictadura y de la democracia. El señor y el campesino en la formación del mundo moderno. Barcelona: Ediciones Península.

Oslender, U. (2008). Comunidades negras y espacio en el Pacífico Colombiano. Hacia un giro geográfico en el estudio de los movimientos sociales. Colombia: Instituto Colombiano de Antropología e Historia, Universidad Colegio Mayor de Cundinamarca y Universidad del Cauca.

Oviedo, R. (2009). Relatos, revueltas y desventuras de la gente entintada del Pacífico Sur. Tumaco: Universidad de Nariño.

Preciado, J. J. (2014). La trasformación del poder político en Tumaco. Pasto: E sismo comunicaciones.

Quiroga, D., y Yunis, J. (2012). Orden social y violencia política en el andén pacífico nariñense. Documento de Trabajo del equipo Violencia Política y Formación del Estado del Cinep. Documento inédito.

Restrepo, E. (1999). Hacia la periodización de la historia de Tumaco. En M. Agier, M. Álvarez, O. Hoffmann y Restrepo (eds.), Tumaco haciendo ciudad (pp. 64-67). Cali: ICANIRD y Universidad del Valle.

Rodríguez, J. D. (2015). Génesis, actores y dinámicas de la violencia política en el Pacífico nariñense. Bogotá: Cinep/PPP y Odecofi.

Ronderos, M. T. (2014). Guerras recicladas. Una historia periodística del paramilitarismo en Colombia. Bogotá: Aguilar.

Rosero, E. (2012). Continuidades y discontinuidades del clientelismo y del familismo en la forma de hacer política en Tumaco. En Sociedad y Economía (22), 231- 260.

Vargas, R. (2003), Drogas, conflicto armado y desarrollo alternativo: una perspectiva desde el sur de Colombia. Bogotá: Acción Andina.

Vásquez, T., Vargas, A., y Restrepo, J. (2011). Una vieja guerra en un nuevo contexto. Conflicto y territorio en el sur de Colombia. Bogotá: Cinep/PPP y Odecofi. 
Vicepresidencia y Observatorio de Derechos Humanos y DIH del Programa Presidencial de Derechos Humanos y DIH. (2009). Dinámica reciente de la violencia en la Costa Pacífica nariñense y caucana y su incidencia sobre las comunidades afrocolombianas. Recuperado de: http://www.acnur.org/t3/ uploads/pics/2774.pdf?view $=1$ 